Ankara Üniversitesi Türk Inkllâp Tarihi Enstitüsü Atatürk Yolu Dergisi

Sayl: 68, Bahar 2021, s.463-494. (DOI: 10.46955/ankuayd.943767)

Makalenin geliş ve kabul tarihleri: 06.08.2020 - 06.04.2021 (Araştırma Makalesi)

\title{
SOĞUK SAVAŞ YILLARINDA BİR AKTÖR: BİIM RADYO
}

\author{
Sinan KIYANÇ*
}

\begin{abstract}
$\ddot{O} Z$
Soğuk Savaş yıllarında Doğu ve Batı blokları kendi ideolojilerini benimsetmek için propaganda araçlarını etkin biçimde kullanmışlardı. Radyonun etki alanının her geçen gün genişlemesi, evlere kolayca ulaşabilmesi nedeniyle onu bu süreçte ön plana çıkarmıştt. Bu amaçla her iki blokta birçok radyo istasyonu kurulmuştur. Bu kapsamda 1958 yllinda Demokratik Almanya Cumhuriyeti'nin Leipzig kentinde Türkiye Komünist Partisi (TKP) Dış Büro tarafindan kurulan Bizim Radyo, 1989 yılına kadar yayın hayatın sürdürmüștü. Türkiye'de devlet radyosunun tek yanlı yayınlar yapması, Bizim Radyo'nun ilgiyle karşılanmasına neden olmuştur. Güçlü alt yapısı ile devlet radyosunun ulaşamadığ yerlere ulaşmıştı. Bizim Radyo'nun güncel gelişmeler ă̆ırlıkl yayını, kısa sürede yerini siyasi ağırlıkl yayınlara bırakmıştı. TKP Dış Büro'nun resmi yayını olarak faaliyet göstermiş, yayınlarını bu doğrultuda hazırlamışst.

Bizim Radyo, Türkiye ile Sovyetler Birliği iliş̧kilerinin şekillenmesinde rol oynamıştır. Türk yetkililerinin, Bizim Radyo yayınlarından rahatsızlıkları nedeniyle faaliyetlerine son verilmesi talebine karşıllk Rus yetkililer, radyonun sinırları içinde olmadığını belirterek talebi yerine getirmemişlerdi. Oysa Bizim Radyo her ne kadar Demokratik Almanya Cumhuriyeti topraklarinda faaliyet gösterse de Sovyetler Birliği denetimi altındayd. Bu çalışmada Bizim Radyo'nun kuruluş süreci ve geçirdiği süreç hakkında bilgi verilmektedir. Bunun yanı sıra Türkiye ile Sovyetler Birliği ilişkilerinde nasıl bir rol oynadığ sorusu, birinci el kaynakların yanı sira araştırma eserler uşı̆ğnda cevaplandırllmaktadır.
\end{abstract}

Anahtar Kelimeler: Bizim Radyo, Nazım Hikmet, Soğuk Savaş, Sovyetler Birliği, TKP.

* Dr., Muğla Sitk1 Koçman Üniversitesi, sinankiyanc@gmail.com, (ORCID: 0000-00020148-9632). 


\title{
AN ACTOR IN COLD WAR YEARS: BİIIM RADYO (OUR RADIO)
}

\begin{abstract}
During the Cold War, East and West blocs effectively used propaganda tools to spread their ideologies. The widening of the radio's area of influence day by day and its easy access to homes made it an important instrument in this process. For this purpose, many radio stations have been established in both blocks. The Communist Party of Turkey (Turkish: Türkiye Komünist Partisi, TKP) Foreign Office set up Our Radio (Turkish: Bizim Radyo) in Leipzig in 1958. It had continued its broadcasting life until 1989. The Bizim Radyo broadcasting gathered a significant popular interest since the state radio broadcasting was generally accepted one-sided. With its substantial infrastructure, its airwaves reached places that the state radio could not reach. Bizim Radio's broadcasts, mainly on current developments, soon became political. It operated as the official call of the TKP Foreign Office and prepared its broadcasting in this direction.

Bizim Radio has played a role in shaping the relations between Turkey and the Soviet Union. Turkish officials expressed their discomfort about Bizim Radio broadcasts and demanded from the Soviet officials their activities to end. The Soviet officials, on the other hand, rejected this offer claimimg the radio did not have relations with the SU. However, according to the Turkish officials, the Bizim Radio was operating in the territory of the Democratic Republic of Germany, but it was under the control of the Soviet Union. The study gives information about the establishment process and flow of Bizim Radio. In addition to this, the question of what role it played in relations of the Soviet Union's with Turkey, will be answered through first hand sources and with research works.
\end{abstract}

Keywords: Bizim Radio, Communist Party of Turkey, Nazım Hikmet, The Cold War, The Soviet Union.

\section{Extended Abstract}

Radio, which was used as a secure communication tool during the First World War, was also used outside the military field after the war. Radio soon became a part of life. This tool of the First World War had become a propaganda way during the Second World War. During the Cold War, many radios started bradcasting for propaganda purposes. One of these radios was Bizim Radio. Bizim Radio has an important role in Turkish political history.

Bizim Radio broadcasts were thoroughly monitored by security forces during the Cold War years due to the states' attitude towards communism. As explained in detail below, Bizim Radio, in its early years, prepared an entertaining content different from the monolithic broadcasts of the state 
radios rather than the propaganda broadcasts to attract the attention of the public. In addition to these broadcasts, the influence of Nazım Hikmet, who was the director of the radio until his death, in the popularity of radio is extremely important. Since it is impossible to prevent radio frequencies, strengthening the radio business is one of the measures taken against such radios.

In addition to Turkish security forces, Bizim Radio broadcasts were checked by the US Central Intelligence Agency, the CIA and partially by the UK. For this reason, the CIA archive has been used in the research. While Turkish security forces monitored Radio broadcasts, the CIA examined the impact of these broadcasts on society. Especially before the coup of May 27, 1960, the CIA wondered whether Bizim Radio's call to the communists had an echo in the streets. In addition, Bizim Radio's support broadcasts for the National Unity Committee have had an echo in the United States with the influence of the CIA.

He played a role in Bizim Radio's foreign policy as well as in Turkish politics. In the days when relations with the Soviet Union deteriorated after the Second World War one of the topics that was discussed in the meetings was Bizim Radio. Many times the issues raised in the face of the Soviet Union, arguing that the radio within its own borders, has rejected Turkey's request for ending the broadcasts. Turkey, the Soviet Union, and East Germany also requested the cessation of Bizim Radio's broadcasting. In East Germany, he gave the same response as the Soviet Union, stating that the radio was not within its borders.

Although the financial burden of Bizim Radio was taken by the Democratic Republic of Germany, the flow of broadcasts was completely managed by the The Communist Party of Turkey (Turkish: Türkiye Komünist Partisi, TKP) Foreign Office. There were sometimes difficulties in preparing publications. It was difficult to get enough information about the developments in Turkey. Newspapers arrived one day later, and the developments in the preparation of the broadcast stream were out of date. In addition to this, it was difficult to follow political developments in Turkey which is located thousands of miles away. In the first years, those who prepared radio broadcasts stayed away from the country for years and followed the developments from their news sources. For example, the coup of May 27, 1960 created great excitement. In Bizim Radio broadcasts, it was claimed that that the coup was made by the left. The perpetrators of the coup were praised. Another example, the same was seen in the publications after the March 12, 1971 Memorandum. Like many leftist publications in the country, he made the same mistake in Bizim Radio, he evaluated and 
supported the March 12, 1971 Memorandum as a leftist intervention. These mistakes were tried to be compensated with publications. In addition to this, the publications were sometimes directed in the light of the information obtained by the Soviet Union intelligence. However, this information consisted of gossip.

Bizim Radio had become one of the devices of provocative and targeting in politics. For this reason, it has been claimed many times that leftist broadcasts cooperated with Bizim Radio. In addition, efforts have been made to identify the Republican People's Party and Bizim Radio many times. It was frequently emphasized in the memoirs of the names who took part in our Radio that the radio was the broadcast organ of the TKP. Our Radio and in publications such as not established a bond with other organic structures left in Turkey was directed harsh criticism for these structures left.

In the study, the establishment and broadcasts of Bizim Radio, which has a an important role place in memories, are discussed. In order to understand radio broadcasting, "Radio's Brief History" is also explained. This section emphasizes the history and importance of radio. The emergence of radio and its broadcasting policies are divided into separate headings. Under these headings, the process of the radio during its establishment and broadcasting life is summarized. Radio as well as the establishment of Turkey's response to criticism is revealed as itself. In addition to this, attention is drawn to the role played by the Soviet Union's relations with Turkey. In the last part of the reduction of the radio's power and political atmosphere in Turkey due to the changes occurring in the radio broadcast is revealed that the termination of life. In the study, the memories, archive documents and research works of the names who took part in the radio are used. It inferred that the radio was one of the important actors in the Cold War years.

\section{Giriş}

Birinci Dünya Savaşı yıllarında güvenli iletişim aracı olarak kullanılan radyo, savaş sonrasında askeri alan dişında da kullanılmaya başlanmıştı. Radyo, kısa süre sonra hayatın bir parçası haline gelmişti. Birinci Dünya Savaşı'nın güvenli iletişim aracı, İkinci Dünya Savaşı yıllarında propaganda aracı haline gelmişti. Soğuk Savaş yıllarında da propaganda amacıyla birçok radyo ortaya çıkmıştır. Bu radyolardan birisi de Bizim Radyo'dur. Bizim Radyo'nun, Türk siyasi tarihinde önemli bir yeri bulunmaktadır.

Bizim Radyo, kuruluşu itibariyle basında yer bulmuştur. Soğuk Savaş yıllarında devletin komünizme karşı tutumu nedeniyle radyo yayınları güvenlik güçleri tarafından sıkı bir şekilde takibe alınmıştır. Aşağıda detaylı bir şekilde belirtildiği üzere, Bizim Radyo ilk yıllarında halkın ilgisini 
çekmek için propaganda yayınlarından ziyade devlet radyosunun tekdüze yayınlarından farklı eğlenceli bir içerik hazırlamıştır. Bu yayınlarının yanı sıra ölümüne kadar radyonun yöneticiliğini yapan Nazım Hikmet'in de etkisi son derece önemlidir. Radyo frekanslarının önlenmesinin imkânsız olduğundan, Türkiye'de radyo işletmeciliğinin güçlendirilmesi, bu gibi radyolara karşı alınan önlemlerden birisidir.

Türk güvenlik güçlerinin yanı sıra ABD Merkezi İstihbarat Teşkilatı, CIA ve kısmen de İngiltere tarafından Bizim Radyo yayınları takip edilmiş̧tir. $\mathrm{Bu}$ nedenle araştırmada CIA arşivinden yararlanılmıştır. Türk güvenlik güçleri, Radyo yayınlarını takip ederken, CIA ise bu yayınların toplum üzerinde etkisini incelemiştir. Özellikle 27 Mayıs 1960 Darbesi öncesinde, Bizim Radyo'nun, komünistlere çağrısının, sokakta yankı bulup bulmadığını merak etmiştir. Bunun yanı sıra Milli Birlik Komitesi'ne destek yayınları, CIA etkisiyle ABD'de yankı bulmuş, darbeyi yapanlara karşı ön yargı oluşmasına neden olmuştur. ${ }^{1}$

Bizim Radyo, Türk siyasetinde olduğu gibi dış politikasında da rol oynamıştır. İkinci Dünya Savaşı sonrasında bozulan Sovyetler Birliği ilişkilerinin iyileşmeye yüz tuttuğu günlerde, yapılan görüşmelerde masaya konulan konulardan birisi de Bizim Radyo'ydu. Birçok kez gündeme gelen konu karşısında Sovyetler Birliği, radyonun kendi sınırları içinde olmadığını öne sürerek Türkiye'nin kapatma talebini geri çevirmiştir. Türkiye, Sovyetler Birliği'nin yanı sıra Doğu Almanya'dan da Bizim Radyo yayınlarının durdurulmasını istemiştir. Doğu Almanya'da, Sovyetler Birliği'nin verdiği yanıtın aynısını, radyonun kendi sınırları içinde olmadığını belirterek olumsuz yanıt vermiştir.

Bizim Radyo'nun mali yükü her ne kadar Demokratik Almanya Cumhuriyeti tarafından karşılansa da yayın akışı tamamen TKP Dış Büro tarafindan yürütülmekteydi. Türkiye'deki gelişmeler 1şı̆̆ında yayınların hazırlanmasında kimi zaman zorluk çekilmekteydi. Türkiye'deki gelişmeler hakkında yeterli bilgi almak zordu. Gazeteler bir gün sonra ulaşmakta, yayın akışı hazırlanana kadar gelişmeler güncelliğini kaybetmekteydi. Bunun yanı sira kilometrelerce uzaklıktan, Türkiye'deki gelişmeleri okumakta zorluk çekilmekteydi. İlk yıllarda radyo yayınlarını hazırlayanlar, yıllarca ülkeden uzak kalmış ve gelişmeleri haber kaynaklarından takip etmekteydiler. Örneğin, 27 Mayıs 1960 Darbesi büyük heyecan yaratmıştı. Bizim Radyo yayınlarında darbenin sol kesim tarafından yapıldığı üzerinde durulmuştu.

1 Sinan Kıyanç, CIA ve Türkiye'de Darbeler, 27 Mayıs 1960 Darbesi, 12 Mart 1971 Muhtırası, 12 Eylül 1980 Darbesi, Talat Aydemir ve Eminsu Darbe Girişimleri, Duvar Yayınları, İzmir, 2020, s. 16. 
Darbeyi yapanlardan övgüyle bahsedilmişti. Bir başka örnek de 12 Mart 1971 Muhtırası sonrasındaki yayınlarda aynı durumun görülmesi olmuştu. Ülkede birçok sol yayın gibi Bizim Radyo'da aynı hataya düşmüş, 12 Mart 1971 Muhtırası'nı sol müdahale olarak değerlendirmiş ve desteklemişti. Bu hatalar yayınlarda telafi edilmeye çalışılmıştı. Bu yayınların yanı sıra kimi zaman Sovyetler Birliği istihbaratı tarafından elde edilen bilgiler 1şığında yayınlara yön verilmişti. Ancak bu bilgiler dedikodudan ibaretti. ${ }^{2}$

Bizim Radyo siyasette tahrik edici ve hedef gösterici dilin aygıtlarından birisi haline gelmişti. Bu nedenle birçok kez sol yayınların Bizim Radyo ile ortak hareket ettiği iddiaları ortaya atılmıştı. Bunun yanı sıra birçok kez Cumhuriyet Halk Partisi ile Bizim Radyo özdeşleştirilmeye çalışılmıştır. ${ }^{3}$ Bizim Radyo'da görev alan isimlerin hatıratlarında, radyonun TKP'nin yayın organı olduğu sık sık vurgulanmıştı. Türkiye'de diğer sol yapılarla organik bir bağ kurulmadığı gibi yayınlarda bu sol yapılara yönelik sert eleştiriler yöneltilmişti.

Çalışmada anılarda geniş bir yer tutan Bizim Radyo'nun ortaya çıkış süreci, kuruluşu ve yayınları ele alınmaktadır. Radyo yayıncılığının anlaşılabilmesi için "Radyo'nun Kısa Tarihi”" başlı̆̆ altında radyonun tarihi ve önemi vurgulanmaktadır. Bizim Radyo'nun ortaya çıkışı ve yayın politikaları ayrı başlıklar altında ele alınmaktadır. Bu başlıklarda radyonun kuruluşu ve yayın hayatı boyunca geçirdiği süreç belirtilmektedir. Bizim Radyo'nun kuruluşu itibariyle Türkiye'deki tepkilerin yanı sıra radyo içinde eleştiriler ortaya konulmaktadır. Bunun yanı sıra Türkiye ile Sovyetler Birliği ilişkilerinde oynadığı role dikkat çekilmektedir. Son kısımda ise radyonun gücünün azalması ve Türkiye'nin siyasi atmosferinde meydana gelen değişim nedeniyle radyonun misyonunu tamamladığını ve yayın hayatına son verildiği ortaya konulmaktadır. Çalışmada radyoda görev almış isimlerin hatıratlarından, arşiv belgelerinden ve araştırma eserlerinden faydalanılmaktadır. Radyonun Soğuk Savaş yıllarında önemli aktörlerden birisi olduğu savunulmaktadır.

2 Erden Akbulut, TKP 1965 Tartışmaları Muhalefet Mektupları, Sosyal Tarih Yayınları, İstanbul, 2011, s. 186.

3 Aclan Sayılgan, Bizim Radyo ve Hoparlörleri, Kardeş Matbaası, Ankara, 1969; Cavit Ersan, Zindanlar, Sinan Yayınevi, İstanbul, 1975, s. 34; Tekin Erer, Yassıada ve Sonrası, Rek-Tur Kitap Servisi, İstanbul, 1965, s. 244-246; Nusret Kirişçioğlu, 12 Mart (İnönüEcevit) ve 1960 Tahkikat Encümeni Raporum, Baha Matbaas1, Ankara, 1973, s. 188189. 


\section{Radyo'nun Kısa Tarihi}

Radyo fikri, 1860 y1lında James Clerk Maxwell tarafindan ortaya atılsa da kullanımı için Birinci Dünya Savaşı'nı beklemek gerekmişti. Savaşın sıcak günlerinde denizcilik alanında kullanılmaya başlanan radyo dalgaları, gemilerin kendi aralarında ve kara ile iletişimini sağlamıştır. Kablosuz iletişimi sağlayan radyo sinyalleri, kısa sürede denizciliğin yanı sıra havacılıkta da kullanılmıştır. Böylece havacılığın da gelişimine önemli katkı sağlamıştır. Radyo sinyallerinin iletişimde kullanılması, bilgi akışının güvenli bir şekilde sağlanmasına neden olmuştu. ${ }^{4}$

Askeri alanda kullanımıyla sınırlı olan radyo, Birinci Dünya Savaşı sonrasında günlük hayatta da kullanılmaya başlamıştır. ABD'nin Pittsburgh kentinde Kasım 1920 yılında, askeri alan dışında, ilk radyo yayını yapılmıştır. Seçim sonuçlarını duyurmak için kullanılan radyo yayınının sürekli hale gelmesi, İngiltere'de BBC tarafindan 14 Kasım 1922 tarihinde gerçekleşebilmişti. BBC tarafindan başlanan sürekli yayın ile radyo, kısa sürede hayatın vazgeçilemez bir parçası haline gelmişti. Her ne kadar radyo cihazlarının pahalılığı sorunu aşılamasa da yayınlar geniş bir kesime ulaşmıştı. $\mathrm{Bu}$ durum dünyanın birçok yerinde radyo istasyonlarının kurulmasını sağlamıştı. Haber yayınları ile başlayan radyo yayıncılı̆̆ı, ağırlığını kültür sanat programlarına ve müzik yayınlarına bırakmıştı.

Türkiye'de radyo yayıncilığı, 8 Eylül 1926 tarihinde kurulan Telsiz Telefon Türk Anonim Şirketi (TTTAŞ) ile başlamıştır. Türk hükümeti radyo istasyonlarının işletme ve yayın hakkını, TTTAȘ adı altında Fransızlar ile kurulan ortak şirkete on yıl süreliğine vermişti. İlk radyo yayını, Eşref Şefik'in "Alo alo muhterem samiin! (dinleyiciler)" Türkçe ve Fransızca anonsu ile 6 Mayıs 1927'de Sirkeci Büyük Postane'de 5 kilovat vericiyle yapılmıştı. Radyo yayını, kimsede radyo alıcısı olmadığından, her akşam postane binasına yerleştirilmiş hoparlörden yapılmıştı. TTTAŞ, İstanbul ve Ankara'da radyo istasyonları kurarak faaliyet göstermişti. Radyo işletmesi 1937 y1lında PTT'ye, 22 May1s 1940 tarihinde Matbuat Umum Müdürlüğü'ne devredilmişti. Radyo işletmeciliği alanında değişiklik bununla sınırlı kalmamış, 26 Temmuz 1943 tarihli 4475 sayılı kanun ile Matbuat Umum Müdürlüğü Basın Yayın ve Turizm Genel Müdürlüğü bünyesinde Radyo Dairesi ve Radyo Fen Heyeti tarafından yürütülmüştü. İstanbul

4 Dean Juniper, "The First World War and Radio Development", The RUSI Journal, C. 148, Sayı: 1, (2003), ss. 84-89.

5 Detaylı bilgi için bakınız: Aysel Aziz, Radyo ve Televizyona Giriș, Ankara Üniversitesi Siyasal Bilgileri Fakültesi Yayınları, Ankara, 1981, s. 7-11; Mihail Kuyucu, "Radyonun Müzik Kutusuna Dönüşümü: Radyo Program Türleri ve Tercih Edilirken Oranları”, EJournal New World Science Academy, C. 8, Say1: 4, (2013), s. 376. 
Radyosu'nun 19 Kasım 1949 tarihinde kurulması ile radyo işletmeciliğinde önemli bir adım atılmıştı. Türkiye'de her ne kadar radyo işletmeciliği alanında kurumsal ve özel girişimler mevcut olsa da istenilen seviyeye ulaşamamıştır. Bu durum Türkiye'de, yurt dışından yayın yapan, propaganda radyolarının yaygınlaşmasına neden olmuştu. Propaganda radyolarının dinlenmesini önlemek için 10 Şubat 1959 tarihinde Bakanlar Kurulu'nun aldığı karar ile 27 ilde radyo istasyonlarının kurulması öngörülse de bu istasyonların kurulması 1964 yılında tamamlanabilmişti. ${ }^{6}$

Radyo, insanların vazgeçilmez haber ve eğlence kaynaklarından olmuştu. Radyonun bu baş döndürücü yayılma hızı, İkinci Dünya Savaşı yıllarında savaşın önemli bir parçası olmasına neden olmuştu. Propaganda, İkinci Dünya Savaşı'nda önemli bir dönüşüm geçirmişti. Sovyetler Birliği'nin zayıf komünizm propagandası karşısında ortaya çıkan Nazi propagandası, kısa sürede Avrupa'da etkili olmuştu. Avrupa'nın her tarafına yayın yapabilecek radyo istasyonlar kuran Naziler, neredeyse radyo olan her eve girmişlerdi. Programlar çok dilli hazırlanmış ve bu programlarda açık açık Nazi propagandası yapılmışı. Sovyetler Birliği'nin son derece zayıf kalan komünizm propaganda yayınlarına, İngiltere'nin "BBC" ve ABD'nin "Voice of America (Amerika'nın Sesi)" radyoları yetişmişti. Savaş meydanlarında verilen mücadelenin bir benzeri radyo istasyonlarında verilmişti. $^{7}$

Soğuk Savaş yıllarında, propaganda faaliyetleri için, radyonun önemi gittikçe artmıştır. Radyo her eve kolayca ulaşabilmenin en kolay yolu olduğundan, dünyanın birçok yerinde propaganda radyo istasyonları kurulmuştu. Güçlü vericiler sayesinde geniş alanlara yayın yapan propaganda radyolarının yanı sıra yabancı üs ve tesislerde yerel yayın yapan radyo istasyonları da kurulmuştur. Daha çok insana ulaşmak için yayınlar çok dilli yapılmaktaydı. Bunun yanı sıra müzik yayınları ile ilgi çekilmeye çalışılmaktaydı. Örnek olarak Türkiye'de bulunan ABD üs ve tesislerindeki radyo istasyonları, $\mathrm{ABD}$ müziğine yer vermekte böylece kültürünü yaymaya

6 İbrahim Sena Arvas, “Türkiye'nin Radyo ile Tanışması ve Türk Telsiz Telefon Anonim Şirketi”, International Journal of Cultural and Social Studies (IntJCSS), C. 4, Say1: 2, (2018), ss. 406-428; Yusuf Devran, Siyasal İktidar-TRT İlişsisinin Dünü, Başlık Yayın Grubu Yayınları, İstanbul, 2011, s. 66; Philo C. Wasburn, Broadcasting Propaganda: International Radio Broadcasting and the Construction of Political Reality, Praeger Pub., 1992.

7 Detaylı bilgi için bakınız: Süleyman Seydi, Zor Yıllar 2. Dünya Savaşı'nda Türkiye'de İngiliz-AIman Propaganda ve İstihbarat Savaşı 1939-1945, Asil Yayın, Ankara, 2006; Sayılgan, a.g.e., s. 5; CIA, The Soviet Foreign Propaganda Apparatus, April 1984, CIA-RDP87T00787R000200170003-4. 
çalışmaktaydı. ${ }^{8}$ Çalışmanın konusu olan Bizim Radyo bu radyolardan sadece bir tanesidir. Her geçen gün artan Sovyet radyolarına karș1, ABD tarafından propaganda radyoları kurulmuştu. ABD'nin propaganda radyoları "Radio Liberty/Radyo Free Europe (Özgür Avrupa Radyosu)" ve "Voice of America (Amerika'nın Sesi)" ile geniş kesimlere ulaşmıştı. ${ }^{9}$

ABD, Nazi Almanya'nın propaganda faaliyetlerine karşı, 1942 yılında kurulan Voice Of America-Amerika'nın Sesi radyosunu, İkinci Dünya Savaşı sonrasında Sovyetler Birliği propagandalarına karşı yeniden düzenlemiştir. Voice of America, 27 dilde yayın yapan ve özellikle Sovyetler Birliği’nin propaganda alanlarında faaliyet göstermiştir. Broadcasting Board of Governors bünyesinde yayınlarına devam eden radyo, 12 Şubat 1942 tarihinde Türkçe yayınlarına başlamıştı. Bu yayınlar İkinci Dünya Savaşı sonrasında (1945-1949) kesintiye uğramıştı. Dışişleri Bakanı M. Fuad Köprülü, 10 Aralık 1951 tarihinde ABD Türkiye Büyükelçisi'nden Amerika'nın Sesi Radyosu'nun röle istasyonunun (aktarıcı) Türkiye'de yeniden açılmasını istemiştir. Bu istek büyükelçi tarafından memnuniyetle karşılanmıştı. ${ }^{10}$

Sovyetler Birliği, İkinci Dünya Savaşı yıllarında elde ettiği tecrübenin de katkısı ile propaganda amaçlı radyo yayınlarına yoğunlaşmıştı. 1929 yılında kurulan Moskova Radyosu/Rusya'nın Sesi Radyosu, İkinci Dünya Savaşı sonrasında çok dilli yayın yapmaya başlamıştı. Korece, Türkçe, Moğolca ve Farsçanın yanı sıra Avrupa dillerinde yayın yapmaktaydı. Moskova Radyosu'nun bu başarısı Sovyetler Birliği'nde yayın faaliyetlerinin yeniden ele alınmasına neden olmuştu. ${ }^{11}$ Demokratik Almanya Cumhuriyeti'nde Sovyetler Birliği'nin kontrolünde Alman Demokratik Radyo Yayın Birliği kurulmuştu. Bu yayın birliği altı kişiden oluşan Milli Yayın Komitesi tarafindan idare edilmekteydi. Komitelerin tamamı OIRT (Organisation Internationale de la Radiodiffusion et Television) olarak adlandırılan, Moskova merkezli organizasyona üyeydiler. OIRT bünyesinde alınan kararlar tüm yayınlar için geçerliydi. 1960 yılında Bükreş’te OIRT tarafindan yapılan toplantıda komünist yayınların tek merkezden (Moskova'dan) yürütülmesi ve yayınların buna göre yeniden şekillenmesi kararlaştırılmıştı. Sovyetler Birliği bunun üzerine faaliyetlerini üç bölgeye ayırmıştı. Ortadoğu, Balkanlar (Yunanistan ve Türkiye) ve Afrika olarak

8 Özden Çankaya, Bir Kitle İletişim Kurumu Tarihi TRT 1927-2000, Yapı Kredi Yayınları, İstanbul 2003, s.52; Sinan Kıyanç, Soğuk Savaş Yıllarında Türkiye'deki ABD Üs ve Tesisleri, Atatürk Araştırma Merkezi Dergisi, Sayı: 101, (2020), s. 232.

9 Linda Risso, "Radio Wars: Broadcasting in the Cold War", Cold War History, C. 13, Say1: 2, (2013), s. 145-152.

10 Kıyanç, a.g.e., s. 16; Aytül Tamer, "Muhayyel Komünizm: Türk Sağının Anti-Komünizm Propagandası", Doğu Batı Dergisi, S. 58, (2011), s. 98.

11 Mark D. Winek, "Radio as a Tool of the State: Radio Moscow and the Eartly Cold War", Comparative Humanities Review, S. 3, (2009), s. 102. 
ayrılan bölgelerde radyo yayınlarına başlanmıştı. Bu radyo istasyonlarının bir kısmı resmi, bir kısmı ise Bizim Radyo gibi korsan yayın yapmaktaydı. Aşağıda ifade edildiği üzere Türkiye Komünist Partisi (TKP) Dış Büro tarafindan Demokratik Almanya Cumhuriyeti'nde kurulan Bizim Radyo, Sovyetler Birliği yetkilileri tarafından sıkça yalanlanmış, görüşmelerde ülke sınırında olmadığından müdahale edemeyeceklerini belirtmişlerdi. ${ }^{12}$ Bizim Radyo her ne kadar resmi yayın dışında ve TKP'nin Sesi Radyosu'ndan farklı yayın akışına sahip olsa da kimi zaman ortak yayınlar yapılmaktaydı. ${ }^{13}$ OIRT bünyesinde yayın yapan birçok radyonun yanı sıra Çin'den yayın yapan Pekin Radyosu'nda da Türkçe yayınlar yer almaktaydı. ${ }^{14}$

\section{Bizim Radyo'nun Kuruluşu}

Bizim Radyo TKP'nin yurtdışı yapılanmasının önemli hedeflerinden birisiydi. Kuruluş süreci, 1956 yılında, TKP Genel Sekreteri İbrahim Bilen (Marat) tarafından başlatılmıştı. Bizim Radyo'nun açıktan komünizm propagandası yapmak yerine, güncel konulara farklı bakış açısı getirmesi ve böylece geniş bir kesim tarafından dinlenmesi amaçlanmıştı. Radyo açıktan TKP'nin resmi yayını görüntüsünden uzak tutulmuştu. Bu politika radyonun ilk yayınlarında açık bir şekilde görülmektedir. Radyo yayınlarında açıktan komünizm ifadesine yer verilmemiş, propaganda radyosu görünümünden özenle kaçınılmıştı. İbrahim Bilen tarafından Leipzig'de son derece gizli yürütülen çalışma sonrasında Demokratik Almanya Cumhuriyeti finansörlüğünde Bizim Radyo kuruldu. 15 Mart 1958 günü test yayınlarına başlamıştı. 15 günlük test yayınlarının tamamlanmasının ardından 1 Nisan 1958 tarihinde, günlük yayınlarına başlamasıyla, resmen kurulmuştu. ${ }^{15}$ Bizim Radyo, test yayını aşamasında, 19 Mart 1958 tarihinde ulusal basında yer alan haber ile tüm ülkeye duyurulmuş̧tu. Hürriyet ve Milliyet Gazetesi haberlerinde "tesadüfen" tespit edilen radyonun, Türkçe yayın yaptığı ve İzmir limanında bulunan Kayseri şilebinden rahatça dinlenebildiğini okuyucularına aktarmıştı. Haberlerde radyonun ismi "muhalefet radyo istasyonu" olarak belirtilmişti. ${ }^{16}$

Radyo'nun ilk kadrosu İsmail Bilen tarafindan özenle seçilmişti. Seçilen isimlerin birçoğu yayın faaliyetlerinde görev yapmış, tecrübeli

12 Say1lgan, a.g.e., s. 6-7

13 Tüstav, TKP Gölcük Davası, TKP'nin Sesi Radyosu "Nerde Bir Komünist Varsa Parti Ordadır”, Tüstav Yayınları, İstanbul, 2004.

14 Detaylı bilgi için bakınız: Vartan İhmalyan, Bir Yaşam Öyküsü, Cem Yayınevi, İstanbul, 1989.

15 Say1lgan, a.g.e., s. 9-10; CIA, Broadcasts to Turkey, CIA-RDP78-03061A000400070004-8.

16 Hürriyet Gazetesi, "Gizli Bir Radyo Tespit Edildi", 19 Mart 1958, s. 1; Milliyet Gazetesi, "Gizli Radyo İstasyonu", 19 Mart 1958, s.1; Milliyet Gazetesi, "Gizli İstasyonun Mahiyeti Anlaşıldı”, 20 Mart 1958, s. 1. 
isimlerdi. Bunun yanı sıra Sertel ailesi Tan Matbaası işletmeciliği yapmış, Tan Matbaası'nın baskına uğraması sonrasında yurtdışına çıkmışlardı. Bu isimler Leipzig'e davet edildi. İlk kadro şu isimlerden oluşmaktaydı: Aram Pehlivan, Sabiha ve Zekeriya Serte ${ }^{17}$ ile kızı Yıldız Serter ve damadı Kürt Memo (Abuzer Özdemir), Hayk Açıkgöz, Anjel Açıkgöz ve Nazım Hikmet... Nazım Hikmet'in yayın kadrosunda yer alması büyük moral olmuştu. Radyo yayınlarında Nazım Hikmet'in ününden faydalanılmış, böylece daha geniş bir kesime hitap edilmesi amaçlanmıştı. Bizim Radyo kurucularından Hayk Açıkgöz hatıratında Bizim Radyo'nun kuruluşunu ve ismini almasını şöyle anlatmaktadır:

“...toplantımızı yaptık, sözü ilk olarak Marat (İsmail Bilen) aldı: 'Yıllar boyu düşümüz nihayet hakikat oldu. Partimizin bir radyosu olacak. Bu, Bizim Radyo. Onun için adının da 'Bizim Radyo' olmasını teklif ediyorum. $\mathrm{Bu}$ radyonun gayesi: Emperyalizme, faşizme ve bağımlılığa karşı, yani bağımsız Türkiye'den, demokrasinden, hürriyetten ve bütün memleketlerle, bilhassa da komşularımızla dostluk ve barış içinde yaşamaktan yana olan her vatanperveri içine alacak bir tek cephenin kurulmasına yardım etmek olacaktır. Tabii ki ayrıca memleketimizde TKP'nin kuvvetlenmesine de yardım edeceğiz..."18

1 Nisan 1958'de resmi yayın hayatına başlayan Bizim Radyo, 31 yıl aralıksız yayın yapmıştır. Bu süreçte birçok değişiklik geçirerek yayın hayatına devam eden Bizim Radyo, 11 Haziran 1989 tarihinde yayın hayatına son verilmişti. ${ }^{19}$

Hayk Açıkgöz'ün anılarında belirttiği üzere Bizim Radyo planlaması çok eskiye dayanmaktaydı. TKP'nin yurtdışına giden üyeleri uzun süre böyle bir yayın organı kurmayı planlamışlardı. Kuruluş sürecinde öylesine hassas davranmışlardı ki, seslerinin tanıdık olacağından ötürü spikerleri, Doğu Bloku ülkelerinde önceden görev almamış olanlardan seçmişlerdi. Türkiye'de polisin bu isimleri seslerinden tanımasından çekinildiğinden yeni

17 Sertellerin Demokratik Almanya Cumhuriyeti'nden ayrılmaları sonrasında Bizim Radyo'nun hedefine oturmuşlardı. Zekeriya Sertel'in Sovyetler Birliği hakkında yaptığı açıklamaları bir karalama kampanyası olarak değerlendiren Bizim Radyo, eski çalışanını sert bir dille eleştirmiştir. Milliyet Gazetesi, "Bizim Radyo Sertel'e Çattı”, 30 Eylül 1978, s. 1.

18 Hayk Açıkgöz, Anadolulu Bir Ermeni Komünistin Anıları, Belge Yayınları, İstanbul, 2006, s. 481-182; Yıldız Sertel anılarında "Bizim Radyo" isminin babas1 Zekeriya Sertel tarafinda konulduğunu belirtmektedir. Yıldız Sertel, Nazım Hikmet ile Serteller, İdeolojileri, Yaşamlarında Bilinmeyenler, Everest Yayınları, İstanbul,2008, s. 166.

19 Mara Kolarova Bilen, Kanatlı Gençlik, Çev. Cemal Kıral, Türkiye Sosyal Tarih Araştırma Vakfi Yayınları, İstanbul, 2003, s. 85 ve 89; Hayk Açıkgöz, a.g.e.; Milliyet Gazetesi, "Bizim Radyo'da Yayına Son”, 09 Haziran 1989, s. 14. 
isimlerin üzerine odaklanılmıştı. Ancak bu isimleri bulmak hiç kolay değildi. Tecrübeli isim olmadan yayın hayatına başlamak son derece riskliydi. Bir ara sesleri değiştirebilecek cihaz arayışına girilmiş, ancak başarılı olunmamıştı. Kısa süre sonra bu çabanın boşuna olduğu ortaya çıkmıştı. Radyo faaliyete geçer geçmez yurtdışından yayın yapan propaganda radyosu olduğu tespit edilmişti. ${ }^{20}$

Bizim Radyo yayın hayatının hemen başında yurtdışından yayın yapan propaganda radyosu olduğu fark edilse de dinleyici sayısını kısa sürede artırmıştı. Bunun temel nedeni, Türkiye'de radyo yayınlarının son derece sinırlı olmasıydı. Bunun yanı sıra sıkıcı ve tekdüze yayınlar, dinleyicileri müzik yayınları yapan yabancı kaynaklı radyolara yönlendirmişti. Demokrat Parti tarafından 1954 Milletvekili Genel Seçimi sonrasında çıkarılan 5545 sayılı Milletvekili Seçim Kanunu'nda yapılan düzenleme ile muhalefetin radyoda propaganda faaliyetleri yasaklanmıştır. ${ }^{21} \mathrm{Bu}$ durum yayınlara da yansımıştı. Hazırlanan programlarda sadece Demokrat Parti değerlendirmelerine yer verilmekteydi. $\mathrm{Bu}$ durum "partizan radyo" tartışmasını da beraberinde getirmişti. Buna örnek olarak, 1 Ekim 1958 tarihinde kurulan Vatan Cephesi için hazırlanan "Yurdun Dört Köşesinden Haberler" isimli programda cepheye katılanların isimleri okunmaktaydı. İsimlerin okunması saatlerce sürdügünden devlet radyosunun dinleyici sayısını azaltmaktaydı. Türkiye'de bu yıllarda radyo alıcısında ciddi artış görülmektedir. Devlet radyosunun tek taraflı yayınına karşın, müzik yayını yapan korsan radyolar sayesinde radyo, günlük hayatın vazgeçilmez bir parçası haline gelmişti. Radyo haber kaynağı olmasından ziyade bir eğlence kutusu haline gelmişti. 1950 yılında 362.456 olan radyo alıcı sayısı, 1955 yılında 998.662'ye ulaşmışt1. 1960 yılında 1.341 .278 'e ulaşan sayı, dört yıl sonra 1964 yılında 2.177.164'e çıkmıştır. Radyo alıcılarının PTT'ye düzenli kayıtlarını yaptırmamalarından, radyo alıcı sayısının verilerden daha fazla olduğu anlaşılmaktadır. ${ }^{22}$

20 Hayk Açıkgöz, a.g.e., s. 487.

21 Resmi Gazete, "Milletvekilleri Seçimi Kanunun Bazı Maddelerinin Değiştirilmesine ve Bazı Maddeler Eklenmesine Dair Kanun, 23 Şubat 1954, Say1: 8641, s. 8253-8254; TBMM, Milletvekilleri Seçimi Kanunun Bazı Maddelerinin Değiştirilmesine ve Bazı Maddelerinin Kaldırılmasına Dair Kanun Layihası ve Dâhiliye, Teşkilatı Esasiye ve Adliye Encümenlerinin Mazbataları, Devre 10, İçtima: F, 13 Haziran 1954, ss. 1-7.

22 Necla Polat, "1946 Çok Partili Dönemin Başlangıcından 1964 TRT’nin Kurulmasına Kadar Türkiye'de Radyo Yayıncılığı”, İstanbul Aydın Üniversitesi Dergisi, C.10 Sayı: 1, İstanbul, (2018), s. 125-137. 


\section{Bizim Radyo'nun Yayın Politikası}

Türkiye'de devlet radyosunun yayın gücü son derece sınırlıydı. Bunun yanı sıra devlet radyosunda ağdalı Türkçe kullanılmaktaydı. Verilen haberler toplumsal gelişmelerden ziyade, mevcut iktidarlarla sınırlıydı. Oysa Bizim Radyo konuları günlük hayattan seçmekteydi. Ağdalı dilden uzak, günlük Türkçe kullanılan Bizim Radyo'da Nazım Hikmet bile konuşmalarında komünizmi açık açık övmek yerine konuşma metninin içinde belli yerlerde kullanmaktaydı. Yayınlarda ana tema komünizm, Sovyetler Birliği değil, toplumun sıkıntılarıydı. Halkı halkın diliyle anlatıyordu. Devlet radyosunda duyulmayan müzik yayını Bizim Radyo'nun bir başka gücüydü. Güçlü yayını nedeniyle devlet radyosunun bile çekmediği birçok yerde Bizim Radyo yayınları kolayca dinlenebilmekteydi. ${ }^{23}$

Bizim Radyo, yayın dilini yakalamak için başlangıçta önemli sorunlar yaşamıștır. Türkiye'de yaşanan gelișmelerin aktarıldığ 1 yayınlarda bu gelişmelere yorumlar eklenmiş, özellikle Nazım Hikmet'in konuşmaları ilgi çekmişti. Nazım Hikmet konuşmalarının yanı sıra radyoya gönderdiği yazılar güncel gelişmeleri yorumlayan, basit bir dille kaleme alınmıştı. Hayatın her alanına yönelik bu yazılar kimi zaman politik propaganda şeklindeydi. Radyonun ülkede komünizmin yasak olmasından dolayı, bu ifadeye olabildiğince yer vermemesi TKP içinde tepkiye neden olmuştu. Bizim Radyo'nun TKP'nin yayın organı olması nedeniyle komünizm ifadesinin kullanılması gerektiğini savunanlar gittikçe artmaktaydı. $\mathrm{Bu}$ tartışmalar radyonun 1960 yıllarının hemen başında yayınlarına yansımıştı. Komünizm ifadesinin kullanılmasında gösterilen hassasiyet sona ermiştir. Yayın politikasında sertleşmeye başlamıştı. Tüm gelişmeleri sert şekilde ele alan ve kimi zaman suçlayıcı bir dil benimsemişti. ${ }^{24}$

Bizim Radyo yayınları 1928 yılında Komintern'in belirlediği stratejiye göre hazırlanmıştı. Bizim Radyo'nun bu unsurlara sıkı sıkıya bağlılı̆̆ı, yayın politikasında eleştirilere neden oluyordu. Yayınların her ne kadar TKP Dış Büro tarafindan şekillendirildiği düşünülse de asıl güç Sovyetler Birliği'ydi. Bizim Radyo çalışanlarından Bilal Şen anılarında Sovyetler Birliği Komünist Partisi Merkez Komitesi'nin yayınlarda etkisini şöyle belirtmektedir:

23 Anjel Açıkgöz, Bizim Radyoda Nazım Hikmet, Tüstav Yayınları, İstanbul, 2004; Bülent Ecevit, "'Bizim Radyo ve Bizim Radyo" Ulus, 14 Şubat 1961, s. 1-2; Süleyman İlaslan, "Ulusal Bütünlükten Kültürel Yozlașmaya: Türkiye'de Yabancı Radyoların Dinlenmesinden Duyulan Kaygilar", İlef Dergisi, C. 3, Say1: 2, (2016), s. 36.

24 Erden Akbulut, TKP MK Dıș Bürosu 1965 Tartışmaları, Tüstav Yayınları, İstanbul 2004, s. 49. 
“O zaman ben sanıyordum ki bu görüşleri Sovyetler'e Marat veriyor. $\mathrm{Bu}$ inançla ona soruyordum: 'Sen mi veriyorsun bu değerlendirmeleri onlara, yoksa onlar mı veriyorlar sana?' Aslında Marat'ın fikir vermesi pek mümkün değil ama o da zaten bu soruyu hiç cevaplandırmadı. Sonradan öğrendim ki Şark Enstitüsü'ne bu fikirleri veren SBKP Merkez Komitesi'nde Türkiye Seksiyonu'na da bakan Ortadoğu sorumlusu Milonov'du."25

Bizim Radyo'nun yöneticiliğini, kuruluşundan 1963 y1lına kadar Nazım Hikmet, sonrasında ise Yakup Demir (Zeki Baştımar) üstlenmişti. Aclan Sayılgan'ın iddiasına göre Nazım Hikmet ve Yakup Demir'in yanı sıra radyo yayınlarında etkin olan bir başka isim de 1938 yılında Nazi Hükümeti görevlisi olarak Ankara'ya atanmış, Ankara Üniversitesi Dil Tarih ve Coğrafya Fakültesinde Almanca dersleri vermiş olan Prof. Herbert Melzig'di. Melzig, 1958 yılında Bizim Radyo'nun Türkçe yayın müdürlügüne getirilmişti. Türkiye'yi son derece iyi tanıyan Melzig'in ülkedeki sol yayınlar olan ANT, Aydınlık ve Yön'de yazı ve röportajları yayınlanmıştı. Bunların yanı sıra "Atatürk'ün Başlıca Nutukları (Ülkü Basımevi-1942)" ile "Kemal Atatürk, Osmanlı'nın Çöküşü Türkiye'nin Dirilişi (Alfa Yayınları-2011)" isimli eserleri hazırlamıştı. ${ }^{26}$

Bizim Radyo Türkçe yayınlarında şivelere de önem vermişti. Böylece daha yaygın dinlenmesi amaçlanmıştı. Türkçe'nin yanı sıra Yunanca, Arapça ve Kürtçe dillerinde yayınlar yapmıştı. ${ }^{27}$ Bizim Radyo Türkiye'deki aşırı sol faaliyetler lehine haberler yaparken, CHP dâhil olmak üzere siyasi partilere ve hükümete sert eleştiriler yöneltmişti. ${ }^{28}$ Siyasilerden, yazarlara kadar birçok ismi Amerikan ajanı olarak suçlamıştı. ${ }^{29}$ Türkiye'nin ABD yanlısı dış politikasına yönelik sert eleştiriler yönelten Bizim Radyo, Türkiye ile Sovyetler Birliği ilişkilerinin iyileşmesi gerektiğini savunmuştur. Türkiye ile Sovyetler Birliği ilişkilerinin iyileşememesinde Türkiye'yi sorumlu gören Bizim Radyo, Türkiye'nin, toprakları üzerinde ABD üs ve tesislerini işgal olarak değerlendirmiş ve izin vermesini bu duruma kanıt olarak göstermiştir. ${ }^{30}$

Bizim Radyo'nun dikkat çeken bir çıkışı da 28 Nisan 1960 öğrenci olaylarında meydana gelmişti. Demokrat Parti iktidarına karşı, İstanbul Üniversitesi öğrencileri tarafından başlatılan gösteriler, Ankara'ya ve oradan

25 Bilal Şen'in Bizim Radyo yayınları hakkında detaylı bilgi için bakınız: Erden Akbulut, Anılar Bilal Şen, Tüstav Yayınları, İstanbul, 2008, ss. 69-75.

26 Sayllgan, a.g.e., s. 12-13.

27 Millet Meclisi Tutanak Dergisi, C. 6, 91. Birleşim, 04 Haziran 1974, s. 10.

28 Milliyet Gazetesi, "Bizim Radyo, Tekrar Neşriyata Başladı”, 14 Mayıs 1959, s. 3.

29 Sertel, a.g.e., s. 178

30 Kıyanç, a.g.m., s. 214; Anjel Açıkgöz, a.g.e. 
ülkedeki birç̧ok şehre sıçramıştı. Nazım Hikmet, 27 Mayıs 1960 Darbesi sonrasında Yunanistan'daki "I Avgi"de yayınlanan röportajında darbenin öncesinde meydana gelen olaylarda Bizim Radyo'nun etkisinin son derece önemli olduğunu belirtmiştir. Nazım Hikmet, olayları organize etmekte Bizim Radyo'nun önemli rol oynadığını ifade etmişti. Olayların bastırılması sonrasında Ankara' da 555K olarak adlandırılan 5 Mayıs 1960 tarihinde saat: 17:00 Kizılay'da meydana gelen öğrenci protestosunun, 27 Mayıs 1960 Darbesi'nde önemli rolü bulunmaktadır. Bu süreçte Bizim Radyo, eylem çağrısı yapmış ve halkı Demokrat Parti iktidarına karşı sokağa çağırmıştı. Türkiye'de ortam iyice gerginleşmiş, 21 Mayıs 1960 tarihinde Harp Okulu öğrencileri yürüyüş gerçekleştirmişti. Olaylar üzerine hükümet sıkıyönetim ilan etmiş ve sansür uygulamıștı. Bunun üzerine Bizim Radyo ön plana çıkmış ve Nazım Hikmet'in 28 Nisan'da Beyazıt Meydanı'nda öldürülen Turan Emeksiz için yazdığı "Beyazıt Meydanı'ndaki Ölü” şiirini yayınlamıştı. ${ }^{31}$ Türkiye' de yaşanan bu gelişmeleri yakından takip eden ABD Merkezi İstihbarat Teşkilatı CIA, olaylarda komünistlerin rol alıp almadığını araștırmıștı. Bizim Radyo'nun komünistleri sokağa çağrıları karşısında kaygılanan CIA, araştırmasında Bizim Radyo'nun çağrılarına karşın komünistlerin olaylara ilgi göstermediğini belirtmiştir. ${ }^{32}$

31 Bir ölü yatıyor

on dokuz yaşında bir delikanlı

gündüzleri güneşte

geceleri yıldızların altında

İstanbul`da, Beyazıt Meydanı`nda.

Bir ölü yatıyor

ders kitabı bir elinde

bir elinde bașlamadan biten rüyası

bin dokuz yüz altmış yılı Nisanında

İstanbul’da, Beyazıt Meydanı`nda.

Bir ölü yatıyor

Vurdular

kurşun yarası

kızıl karanfil gibi açmış alnında

İstanbul`da, Beyazıt Meydanı`nda.

Bir ölü yatacak

toprağa şıp şıp damlayacak kanı

silâhlı milletimin hürriyet türküleriyle gelip

zaptedene kadar

büyük meydanı.

May1s 1960

Detaylı bilgi için bakınız: Sertel, a.g.e., ss. 187-200.

32 Kıyanç, a.g.e., s. 49; Bayram Akça ve Sinan Kıyanç, "CIA ve 27 Mayıs 1960 Darbesi", Tarih Okulu Dergisi, Sayı: 36, (2018), s. 535; CIA, Turkish Communist Sees Coup in Turkey as Step Forward, 8 Temmuz 1960, CIA-RDP78-03107A000600020021-1. 
Demokrat Parti aleyhine yayın yapan hatta 27 Mayıs 1960 Darbesi öncesinde yaşanan öğrenci olaylarında ülkedeki komünistleri sokağa çağıran Bizim Radyo, Milli Birlik Komitesi'ni destekleyen yayınlar yapmıştı. Demokrat Parti iktidarına sert eleştiriler yönelten radyo, Milli Birlik Komitesi üyelerini övmüştür. Kısa süre sonra Milli Birlik Komitesi'nin NATO ve Batı Bloku yanlısı bir tutum sergilemesi üzerine, bu tutumundan vazgeçmiş ve sert eleştiriler yöneltmiştir. Bunun bir örneği ise Türkiye İşçi Partisi hakkındaki yayınlarında görülmektedir. Türkiye İşçi Partisi'nin kuruluşu itibariyle destek yayınları yapan radyo, Çekoslovakya'da yaşanan olayların, Türkiye İşçi Partisi Genel Başkanı Mehmet Ali Aybar tarafından eleştirilmesi sonrasında tavır değiştirerek Aybar'a ve partiye sert eleştiriler yöneltmişti. Radyo, TKP içindeki kavgalarda da açıktan tavır takınmıştır. Gelişmeler karşısında sert bir dil benimsemiştir. Türkiye Komünist Partisi Genel Sekreterliği için Zeki Baştımar (Yakup Demir) ile Mihri Belli çekişmesinde Baştımar tarafını tutmuş, Mihri Belli'ye yönelik sert eleştirilerde bulunmuş, Belli'yi ABD-CIA ajanı olarak suçlamıştı. ${ }^{33}$

Bizim Radyo, Türkiye'de 1968 sonrası sol kesimde yaşanan parçalanmada da taraf olmuştu. Bu süreçte Milli Demokratik Devrimciler hareketini sert bir dille eleştirmişti. 21 Kasım 1970 tarihli "Milli Demokratik Devrimciler ve Gençlik Hareketi” başlıklı yayında, Türkiye'deki Maocuların gençlik ve işçi hareketlerine sızarak, kanlı faşist yöntemler uyguladıklarını ve bu faaliyetlerin Pekin tarafından yönlendirildiğini iddia etmişti. ${ }^{34}$

Türkiye'deki sağ sol çatışmasında Bizim Radyo etkili bir rol oynamıştı. C. L. Sulzberger tarafından kaleme alınan yazıda, Türkiye'ye yaşanan gelişmelerde sol grupların Demokratik Almanya Cumhuriyeti ile bağlantılarına yer vermiştir. Demokratik Almanya Cumhuriyeti'nden desteklenen bu öğrencilerin Bizim Radyo tarafından sürekli yönlendirildiklerini iddia etmiştir. ${ }^{35}$ Türkiye'de anarşi olayları sürecinde sol grupların bazılarının Sovyet Bloku ülkeleri tarafından desteklendiği iddiaları ortaya atılmış, bu konuda somut bazı deliller olsa da nitelikli bir kanıt bulunmamıştı. Bizim Radyo'nun yayınlarında silahlı bir devrim çağrısı, bu iddialar karşısında ortaya konulan en önemli delillerden birisidir. ${ }^{36}$ Bizim Radyo, 12 Eylül 1980 Darbesi öncesinde TÖB-DER (Tüm Öğretmenler

33 Sayılgan, a.g.e., s. 12 ve 14.

34 Milliyet Gazetesi, "Bizim Radyo Türkiye'deki Gençlik Olaylarını Yorumladı”, 04 Aralık 1970, s. 1 ve 9.

35 Cyrus Leo Sulzberger, "Nihilism-Turkish Style", The New York Times, 25 Ağustos 1972, s. 33.

36 Marvine Howe, "Turk is Called a Product of Violence in His Nation", The New York Times, 17 May1s 1981, s.18. 
Birleşme ve Dayanışma Derneği) ve POL-DER (Polis Derneği) faaliyetlerine destek yayınları yapmıştı. TKP, bu derneklerin parti ile herhangi bir organik bağının olmadığını açıklasa da her iki dernek için Bizim Radyo destek yayınları yapmıștır. Ancak, Türkiye'deki sol grupların Sovyetler Birliği ve Demokratik Almanya Cumhuriyeti ile bağlantılı olduğu iddiasını sadece Bizim Radyo üzerinden kanıtlamaya çalışmak, böylesine bir iddia için son derece zayıf kalmaktadır. Çünkü yukarıda da belirtildiği üzere, Bizim Radyo'nun yayın politikası farklılık gösterdiği gibi, yaptı̆̆ 1 çağrılarında toplumda destek bulmadığı görülmektedir. ${ }^{37}$

Bizim Radyo ilk yıllarında geniş bir kesime ulaşmak için, yumuşak bir dil benimsemiştir. Nazım Hikmet'in yönetimindeki radyo, halkın diliyle günlük gelişmeleri yorumlamaktaydı. Kilometrelerce uzaktan Türkiye'deki gelişmeleri takip etmek son derece zordu. Gelişmeler bir gün sonra ellerine geçen gazetelerden öğrenilmekteydi. Bir başka sorun ise yıllardır Türkiye'den uzakta yaşayan insanların, Türkiye'deki gelişmeleri yorumlamalarıydı. Tüm bu zorluklar ve aksaklıklara karşın radyo geniş bir kesime ulaşabilmişti. Radyonun yayın dilinin yumuşak olması, TKP içinde sert eleştirilere neden olmuştu. Bu eleştirilere göre, radyo TKP yayını olması nedeniyle partinin savunduğu politikalar doğrultusunda yayınlarını hazırlamalıydı. Bu eleştiriler radyonun dilinin değişmesine neden olmuştu. Kısa süre sonra radyo, ilk yıllarında benimsediği yumuşak dilden vazgeçerek sert bir dil benimsemiştir. Bunun yanı sıra ülkedeki gelişmeler karşısında hedef göstermeye başlamıştı. Ülkedeki birçok ismi ABD-CIA ajanı olarak suçlamıştı.

\section{Bizim Radyo’ya Eleștiriler ve Tepkiler}

Bizim Radyo yayın hayatına başlamasıyla beraber eleştirileri ve tepkileri de beraberinde getirmiştir. Yayın hayatına başlamasından kısa süre sonra Türkiye'de propaganda faaliyetleri yürüttügü ortaya çıkması üzerine tepkiler ortaya çıkmıştır. Çalışmanın birçok yerinde belirtildiği üzere gerek iç politikada gerekse Sovyetler Birliği ilişkilerinde Bizim Radyo'nun yayınları yıkıcı faaliyetler kapsamında değerlendirildiğinden şikâyet edilmiştir. Türkiye'de resmi makamlarca tepkiyle karşılaşmasının yanı sıra yayın politikası bakımından radyo içi eleştirilere de maruz kalmaktaydı.

TKP Dış Büro üyeleri kimi zaman Bizim Radyo yayın politikalarını ve görev dağılımını eleştirmekten çekinmemişlerdi. Bu eleştiriler radyonun ilk

37 Sertel, a.g.e., s. 170; Bülent Gökay, Soviet Eastern Policy and Turkey, 1920-1991: Soviet Foreign Policy, Turkey and Communism, Routledge Taylor and Francis Group, New York, 2006, s. 108-109; CIA, Turkey: A Regime in Trouble, 4 June 1971, CIARDP79R00967A001400030009-5. 
toplantısında bile ortaya çıkmıştı. Sertel ailesi ile İsmail Bilen arasında fikir ayrılıkları vardı. Yayınlar çok dilli hazırlanmaktaydı ve bu kapsamda Kürtçe yayınlar Sertel ailesinin damadı Abuzer Özdemir tarafından sunulmaktaydı. Ancak radyoda Abuzer'den başka Kürtçe bilen yoktu. Bu durumu Hayk Açıkgöz eleştirmiş̧ti. Açıkgöz, Kürtçe yayının son derece hassas olduğunu, bu nedenle kontrol edilmeden yapılmasının riskli olacağını belirtse de bu tepki destek bulmamıştır. ${ }^{38}$

Büyük bir titizlikle yürütülmeye çalışılan yayınlarda kimi zaman partinin haberi olmadan yöneticilerin aldığı kararlar doğrultusunda yayınlar yapılmaktaydı. TKP Dış Büro üyesi Bilal Şen'in 1963 yılında Bizim Radyo yayınlarına yönelik eleştirileri parti içinde rahatsızlığa neden olmuştu. $\mathrm{Bu}$ eleştiriler Bilal Şen ile sınırlı kalmamıştı. Birçok üye Bilal Şen'in eleştirilerine destek vermişti. Bilal Şen'in Bizim Radyo'nun Türkiye'deki gelişmeleri yanlış yorumladığı, gelişmeleri okuyamadığ 1 eleştirileri karşısında TKP Dış Büro'nun tepkisi sert olmuștu. Bilal Şen, TKP Dış Büro üyeliğinden, ardından partiden ihraç edilmişti. TKP Genel Sekreteri Yakup Demir raporunda Bilal Şen'in Bizim Radyo tartışmaları nedeniyle ihraç edildiğini doğrulamıştır. ${ }^{39}$

Bizim Radyo içerideki eleştirilerin yanı sıra Türkiye'de geniş bir kesimin de hedefindeydi. Radyo, Türkiye'de güvenlik birimleri tarafindan yakından takip edilmiştir. Türk güvenlik güçlerinin yanı sıra CIA, Bizim Radyo faaliyetlerini yakından takip etmiş ve bu yayınların toplum üzerinde etkisini incelemişti. ${ }^{40}$ Türkiye'de de görev yapan ABD Ulusal Güvenlik danışmanlarından Paul Henze, 1987 yılında kaleme aldığı makalede Bizim Radyo faaliyetlerine yer vermiştir. Henze, Bizim Radyo'nun Sovyetler Birliği tarafından yayınlanan propaganda radyolarından olduğunun altını çizerken, insanlar üzerinde etkisinin zayıf olduğunu belirtmiştir. ${ }^{41}$

Bizim Radyo, Türkiye'de siyaset gündeminde de yer bulmuştu. Demokrat Parti'nin TBMM nezdinde yaşanan siyasi olaylar karşısında "Cumhuriyet Halk Partisinin yıkıcı, gayrimeşru ve kanun dışı faaliyetlerinin memleket sathında cereyan tarzı ve bunların mahiyetinin nelerden ibaret

38 Hayk Açıkgöz, a.g.e., s. 483.

Akbulut, a.g.e., s.13-14.

40 CIA, 1957-59 Propaganda Forgeries, CIA-RDP78-00915R001200080005-5; CIA, SinoSoviet Bloc Propaganda Forgeries 1 January 1957 to 1 July 1959, March 1960, CIARDP78-02646R000300130001-0.

41 Paul B. Henze, "Out of Kilter-Greeks, Turks \& U.S. Policy", The National Interest, No: 8, (Summer 1987), s. 75; Paul B. Henze, Turkey and Atatürk's Legacy: Turkey's Political Evolution, Turkish-US Relations and Prospects fort he 21st Century, Research Centre for Turkestan and Azerbaijan Publishing, 1998, s. 71. 
olduğunu tahkik, tespit ve memleketin her tarafinda yaygın bir halde görülen kanun dışı siyasi faaliyetlerin muhtelif sebeplerine intikal etmek, matbuat meselesi ile adli ve idari mevzuatın ne suretle tatbik edilmekte olduğunu tetkik eylemek üzere Meclis tahkikatı açılmasına dair" kararın Ç maddesinde Bizim Radyo'ya yer verilmiş, gerekçe şu şekilde belirtilmişti: "Bizim Radyo namındaki komünist radyosunun Halk Partisi'ne ait bir radyo olarak göstermek suretiyle halkı bu yayınları dinlemeye sevk etmek ve umumi efkârı bu vahim neşriyatın zararlı tesirlerine maruz bırakmak."42 Tahkikat Komisyonu'nda gündeme gelen Bizim Radyo, 27 Mayıs 1960 Darbesi sonrasında kurulan Yassiada Mahkemesi (Yüksek Adalet Divanı Yargılamaları) kayıtlarında da yer almıştır. Mahkeme Başkanı Salim Başol'un darbe öncesinde yaşananlar hakkında sorduğu bir soruya Adnan Menderes cevabında Bizim Radyo'ya yer vermiştir. Bizim Radyo'nun yayınlarının toplumu tahrik ettiğini belirten Menderes, bu durumun yaşanan gerginlikte rol oynadığını savunmuştur. ${ }^{43}$

Türkiye'de sol ideolojiyi temsil eden Türkiye İşçi Partisi, 10 Ekim 1965 tarihindeki Milletvekili Genel Seçimine katılmıştı. Mehmet Ali Aybar'ın genel başkanlık koltuğuna oturduğu Türkiye İşçi Partisi, ülkedeki sol tarihinde önemli bir başarı elde etmişti. Bu havadan Bizim Radyo'da etkilenmiş ve Türkiye İşçi Partisi'ni desteklemişti. ${ }^{44}$ Fethi Naci, Türkiye İşçi Partisi'nin elde ettiği başarıyı şöyle belirtmiştir: "Türkiye'de 'Sol' ilk defa 10 Ekim seçimlerinde birleşti, hep bir ağızdan konuştu, kişisel kırgınlıkları, küskünlükleri, anlaşmazlıkları bir yana bıraktı; bir büyük ve yüce amaç uğruna birçok şeyi unutmak gereğini duydu". ${ }^{45}$ Seçimde Adalet Partisi ilk sırada yer alırken, en dikkat çeken ise Türkiye İşçi Partisi'nin 15 milletvekili ile TBMM çatısı altında temsil edilmesiydi. ${ }^{46}$ Ancak sol kendi içinde bu durumu eleştirmekten de geri kalmamıştı. Münevver Andaç, Bilal Şen'e gönderdiği 19 Ekim 1965 tarihli mektupta Adalet Partisi'nin ilk sırada yer almasından duyduğu rahatsızlığı belirtmiştir. Bu durumun nedenleri arasında

42 Resmi Gazete, Say1: 10484, 19 Nisan 1960, s. 1178/a.

${ }^{43}$ Ecevit, a.g.e., s. 1-2.

44 Kemal Karpat, "Socialism and The Labor Party of Turkey", Middle East Journal, C. 21, Say1: 2, (Spring 1967), s. 160.

45 Fethi Naci, "Soyalizmin Türkçesi”, Yön Dergisi, Sayı: 135, (29 Ekim 1965), s. 6; Barıș Ünlü, Bir Siyasal Düşünür Olarak Mehmet Ali Aybar, İletişim Yayınları, İstanbul 2002, s. 200.

46 Fethi Naci bu durumu şöyle belirtmektedir: "Meyhaneler, salonlar, kitaplar, dergiler, gazeteler, açık oturumlar, sokaklar, meydanlar derken sosyalizm sonunda parlamentoya girdi. Sosyalizmin parlamentoya girmesi, yeni bir dönemin başlangıcı olacaktı: Artık Türkiye'de sosyalizmin Türkçesi başlayacaktır." Fethi Naci, a.g.e. 
Bizim Radyo'nun yetersizliğini de göstermişti. Bu nedenle radyonun bir buçuk yıllık yayınlarının gözden geçirilmesi gerektiğini istemişti. ${ }^{47}$

Bizim Radyo'ya karşı eleştiriler sadece devlet ve să̆ kesimden gelmemiştir. Sol kesim tarafından yakinen tanınan Mihri Belli, 08 Aralık 1970 tarihinde Milliyet Gazetesi'nde kaleme aldığı yazıda Bizim Radyo yayınlarını sert bir dille eleştirmiş, radyoyu oportünizm savunuculuğu yapmakla suçlamıştı. Belli'ye göre, Bizim Radyo yayın politikası bakımından devrimci bir politika görüntü vermemekte, farklı düşünenleri emperyalist olarak suçlamakta, Stalin'i putlaştırmaktaydı. Belli, Dev Genç üyesi üniversitelilerin sıkıyönetim tarafından yargılanmalarını "emperyalizmin ajanları, emperyalizmin ajanlarını yargılıyor" başlığıyla sunmasını iddialarına kanıt olarak göstermişti. ${ }^{48}$ Bizim Radyo'nun eleştirileri bununla sınırlı kalmamıştı. Sol hareket içindeki ayrışmada bu tutumunu devam ettirmiş ve birçok isme karşı yayınlar yapılmıştır. ${ }^{49}$

\section{Türkiye Sovyetler Birliği İlişkilerinde Bizim Radyo}

Türkiye ile Sovyetler Birliği ilişkileri, İkinci Dünya Savaşı sonrasında Sovyetler Birliği'nin tehditkâr tutumu nedeniyle bozulmuştu. Bu nedenle Türkiye, ABD yanlısı bir dış politika benimsemiş ve bu politikasını, Soğuk Savaş süresince devam ettirmiştir. Ancak Soğuk Savaş yıllarında yaşanan bazı gelişmeler karşısında Türkiye'nin ABD tarafından yalnız bırakılması, onun Sovyetler Birliği'ne yakınlaşmasına neden olmuştur. Özellikle Kıbrıs meselesinde Türkiye'nin politikasının ABD tarafından desteklenmemesi, Kıbrıs meselesi üzerinden Türkiye ile Sovyetler Birliği ilişkilerinde yeni bir dönemin başlangıcı olmuştur. Bunun ilk adımı Adnan Menderes zamanında atılmıştır. 27 Mayıs 1960 Darbesi'nin hemen öncesinde Adnan Menderes, Sovyetleri Birliği'ne ziyaret planlamış ancak darbe nedeniyle ziyaret gerçekleşememişti. Darbe yönetiminin ABD yanlısı tutumu, Sovyetler Birliği ile ilişkilerin iyileşmesini engellemişti. 27 Mayıs 1960 Darbesi sonrasında Sovyetler Birliği yeni yönetim ile ilişkileri kurmak için yoğun çaba göstermişti. Sovyetler Birliği Türkiye Büyükelçisi Nikita Rijov sık sık Ankara'da görüşmeler yapmış, ilişkilerin iyileşmesi için yoğun çaba

47 Akbulut, a.g.e., 2011, s. 45-46.

48 Mihri Belli, "Mihri Belli, Bizim Radyonun Yayınlarına Cevap Verdi”, Milliyet Gazetesi, 08 Aralık 1970, s. 1 ve 9; Mihri Belli 13 Mart 2006 tarihinde Milliyet Gazetesi'ne verdiği röportajda da Bizim Radyo yayınlarını eleștirmiști. Bizim Radyo yöneticilerinin Stalin'i putlaştırdığını iddia etmişti. https://www.milliyet.com.tr/pazar/hicbir-zaman-bagnazstalinci-olmadim-149365/(Erişim Tarihi: 11.06.2020).

49 Vehbi Ersan, 1970'lerde Türkiye Solu, İletişim Yayınları, İstanbul, 2014. 
harcamış, ekonomik yardım vaatlerinde bulunmuştu. Ancak Milli Birlik Komitesi böylesine bir yakınlaşmaya sıcak bakmıyordu. ${ }^{50}$

Bizim Radyo'nun Demokrat Parti aleyhindeki yayınları, 27 Mayıs 1960 Darbesi sonrasında yeni yönetime destek şeklini almıştı. ${ }^{51}$ Sovyetler Birliği'nin yeni yönetime yakınlaşma çabalarında Bizim Radyo gündeme gelmişti. Bülent Ecevit, Ulus'ta kaleme aldığı yazıda, Sovyetler Birliği'nin yakınlaşma çabasının, Bizim Radyo yayınları nedeniyle samimi olmadığını belirtmişti. ${ }^{52}$ Cemal Gürsel 1961 yılında Bizim Radyo yayınlarına tepki göstermiş ve Sovyetler Birliği'nin yayınlara derhal son vermesi gerektiğini belirtmişti. ${ }^{53}$

Bizim Radyo'yu yakından takip eden ülkelerden birisi de İngiltere’ydi. İngiltere'nin Türkiye Büyükelçisi ile Dışş̧leri Bakanı Selim Sarper'in görüşmelerinde Bizim Radyo gündeme gelmişti. Demokratik Almanya Cumhuriyeti'nden yayın yapan Bizim Radyo'nun Türkiye'deki mevcut yönetime karşı eleştirilerini belirten İngiltere Büyükelçisi, yayın tutanaklarını Sarper'e vermişti. Bu durum Türkiye ile Sovyetler Birliği ilişsilerinin iyileşmesi önündeki engellerden birisi olmuştu. TBMM'de dış politika üzerine yapılan bir görüşmede Bizim Radyo gündeme gelmişti. 1962 yılında Dışişleri Bakanlığı Bütçe görüşmesinde YTP grubu adına konuşan Fahrettin Kerim Gökay, Bizim Radyo yayınlarına değinmişti. Gökay, Bizim Radyo'nun propagandalarını eleştirmiş ve durdurulması gerektiğini ifade etmiştir. 1963 yllında iki ülke ilişkilerinin iyileşme sürecine girmesi üzerine Dışişleri Bakanı Feridun Cemal Erkin, TBMM'de yaptı̆̆ ülke arasındaki ilişkilerin iyileşme sürecine değinerek bu havada Bizim Radyo'nun da yayınlarından vazgeçmesi gerektiğini vurgulamıştı. ${ }^{54}$

Kıbrıs'ta yaşanan gelişmeler karşısında ABD ve Batı Bloku'nun Türkiye'ye destek vermemesi, Türkiye'yi Sovyetler Birliği'ne yakınlaştırmıştı. Sovyetler Birliği'nin, Kıbrıs'ta yaşanan gelişmeler karşısında Türkiye'nin politikasını desteklemesi ile iki ülke arasında İkinci

50 Vefa Kurban, “1950-1960 Yıllarında Türkiye ile Sovyetler Birliği Arasındaki İlişkiler”, Çağdaş Türkiye Tarihi Araştırmaları Dergisi, C. 14, Sayı: 28, (2014), ss. 253-282.

51 Bizim Radyo'nun 27 Mayıs 1960 darbesi sonrasında Nazım Hikmet'in seçme konuşmalarından anlaşıldığı üzere yeni yönetim sempati ile karşılanmıştı. Ancak kısa süre sonra Sovyetler Birliği’nin istediği adımlar atılmaması üzerine Bizim Radyo yeni yönetime karşı eleştirel yayınlar yapmaya başlamıştır. Detaylı Bilgi için bakınız Anjel Aç1kgöz, a.g.e., s. 137-146.

52 Ecevit, a.g.e., s.1-2.

53 Sayılgan, a.g.e., s. 10.

54 Eren Tellal, Uluslararası ve Bölgesel Gelişmeler Çerçevesinde SSCB-Türkiye İlişkileri 1953-1964, Mülkiyeliler Birliği Vakfı Yayınları, Ankara-2000, s. 205-206. 
Dünya Savaşı sonrasında yaşanan soğukluk son bulmuştu. ${ }^{55}$ Türkiye'nin dış politikasında rota değişikliği yaşanırken Bizim Radyo, Kıbrıs meselesinde tavrını belirlemişti. Adanın, İngiltere ve ABD ekseninde olmasına karşı çıkmıştır. Bunun yanında adanın, her yurttaşın eşit şartlar altında yaşadığı, bağımsız bir devlet olması gerektiğini savunmuştu. Bizim Radyo, Kıbrıs'ın bağımsız olması yanında tavır koyarken, Marksçı-Leninci parti AKEL'e karşı tavır takınmaktan da özellikle sakınmıştır. ${ }^{56}$

Türkiye ile Sovyetler Birliği ilişkilerindeki yeni dönem iki ülke arasındaki birçok sorunun masaya yatırılmasını da sağlamıştır. ${ }^{57}$ Kıbrıs'ta yaşanan gelişmeler karşısında Türkiye ile Sovyetler Birliği ilişkilerinin iyileşme göstermesi, Bizim Radyo için en büyük sorunlardan birisiydi. Türkiye'deki yönetimi eleştiri yağmuruna tutan Bizim Radyo'nun Sovyetler Birliği ilişkilerinin geliştirilmesini desteklemesi iki farklı tutum sergilemesine sahne olmuştu. Hükümetleri ağır bir şekilde eleştirirken, Sovyetler Birliği ile ilişkilerde olumlu atılan adımlarda övgüler yağdırmaktaydı. Bu süreçte Bizim Radyo, Türkiye'nin Sovyetler Birliği ilişkilerini ekonomik ve kültürel alanda ilerletmesi gerektiği üzerinde durmuştur. ${ }^{58}$

Türkiye ile Sovyetler Birliği arasındaki ilişkilerin iyileşmesi, Bizim Radyo'yu gündeme getirmişti. Kosıgin'in Türkiye ziyareti öncesinde Bizim Radyo yayınları, Türk basınında yer bulmuş ve bu kapsamda Demokratik Almanya Cumhuriyeti'nden yayın yapan radyonun, Türkiye'ye yönelik eleştirileri nedeniyle Kosıgin' in ziyareti eleştirilmişti. Bu kapsamda Türkiye İnsan Hakları Derneği Başkanı Refik Korkut, kaleme aldığı yazıda Bizim Radyo'nun yayınlarına değinerek, Kosıgin'in Türkiye ziyaretini samimi bulmadığını belirtmiştir. Korkut, Bizim Radyo'nun eleştirel ve propaganda yayınlarının Sovyetler Birliği'nin Türkiye'ye bakışını ortaya koyduğunu ifade etmiştir. ${ }^{59}$ Tercüman gazetesinde Ahmet Kabaklı'nın kaleme aldığı “Dostluk Tiyatrosu” başlıklı yazıda Bizim Radyo'nun ismini vermese de demir perde ülkelerinden yayın yapan radyoların Türkiye aleyhine yayınlarına değinerek, Türkiye-Sovyetler Birliği ilişkilerinin iyileşmesi sürecini eleştirmiştir. ${ }^{60}$

55 Musa Qasımlı, Türkiye-Sovyet Sosyalist Cumhuriyetleri Birliği İlişkileri 1960-1980, Atatürk Araştırma Merkezi Yayınları, Ankara, 2013, s. 64-74.

56 Akbulut, a.g.e., 2004, s.37-38; Tüstav, a.g.e., 2002, s. 19,24,97.

57 Türkiye Cumhuriyeti Dışişleri Bakanlığı, Dışişleri Belleteni Ekim-Aralık 1964, Sayı: 3, s. 18.

58 Akbulut, a.g.e., 2004, s. 38-39.

59 Qasımlı, a.g.e., s. 228-229.

60 Ebru Gençalp, “Sovyet Başbakanı Kosıgin'in Türkiye’yi Ziyaretinin Basında Değerlendirilmesi”, Hacettepe Üniversitesi Türkiyat Araştırmaları Dergisi, Sayı: 30, (Bahar 2019), s. 67. 
Sovyet Başbakanı Kosıgin'in 20-27 Aralık 1966 tarihli ziyareti ülkede destek ve tepkilerin gölgesinde gerçekleştirildiğinde masaya konulan konulardan birisi de Bizim Radyo'ydu. Türk yetkililer Kosıgin'e Bizim Radyo'nun iki ülke arasında büyük sorun teșkil ettiğini belirtmișlerdi. Bizim Radyo yayınlarının bir an önce durdurulmasını istemişlerdi. Kosıgin, Bizim Radyo'nun Sovyetler Birliği topraklarında faaliyet göstermediğinden, bir başka ülkedeki yayınlara müdahale edemeyeceklerini belirtmişti. ${ }^{61}$

Kosıgin, dikkat çeken Türkiye ziyaretinde Cumhurbaşkanı Cevdet Sunay'ı Sovyetler Birliği'ne davet etmişti. Kosıgin'in ziyaretinden üç ay sonra iki ülke arasında "Türkiye Cumhuriyeti ile Sovyet Sosyalist Cumhuriyetler Birliği Arasında Bazı Sınai Tesisler Kurulması için Sovyetler Birliği Tarafından Türkiye'ye Teslim Edilecek Teçhizat ve Malzeme ile Sağlanacak Teknik Hizmetlere ve Bunlarla İlgili Ödeme Şartlarına Dair Anlaşma" imzalanmıştı. Bu anlaşma ile iki ülke ilişkilerinde önemli mesafe kat edilmişti. ${ }^{62}$ Cumhurbaşkanı Cevdet Sunay bunun üzerine Sovyetler Birliği'ne, 12-21 Kasım 1969 tarihleri arasında resmi ziyarette bulunmuştu. Sunay'ın heyetinde TRT ve AA temsilcileri de yer almıştı. TRT ve AA yetkilileri, Moskova Radyosu ve TASS Ajansı yetkilileri ile görüşmüşlerdir. Görüşmede her geçen gün daha iyiye giden iki ülke ilişkilerinde basın yayın konusunda da adımlar atılması ele alınmıştı. Bunun yanı sıra görüşmede Bizim Radyo meselesi gündeme gelmiş, Türk yetkililer Bizim Radyo yayınlarının iki ülke ilişkilerine zarar verdiğinden, yayınlarına son verilmesini istemişlerdi. Rus yetkililer ise Bizim Radyo ile ilişkilerinin olmadığını, farklı ülkeden yayın yaptığını belirtmişlerdi. ${ }^{63}$

Türkiye ile Sovyetler Birliği ilişkileri her ne kadar sancılı bir yapıya sahip olsa da Kıbrıs meselesi sonrasında yaşanan gelişmeler, iki ülke iliş̧ilerini normalleştirmişti. Ekonomik meselelerin ağırlıklı olduğu iki ülke ilişkilerinde, 12 Mart 1971 Muhtırası sonrasında bakış açısı değişmişti. Ülkede yükselen sola karşı yapılan askeri müdahale sonrasında kapsamlı tutuklamalar yapılmıştı. Bu süreçte Türkiye'de artan solun nedeni olarak Bizim Radyo ve Sovyetler Birliği görülmüştü. Oysa Türkiye'de güçlenen solun Sovyetler Birliği ile ilgisi yoktu. Sol ağırlıklı olarak Çin'e sempati ile bakmaktaydı. Sovyetler Birliği ile Çin ayrışması Türkiye'de yankı bulmuş, Sovyetler Birliği'ne tepkiye neden olmuştu. Bu durum iki ülke ilişkilerinde

61 Eren Tellal, "SSCB'le İlişkiler”, Türk Dış Politikası Kurtuluş Savaşından Bugüne Olgular, Belgeler, Yorumlar 1919-1980, C.1, ed. Baskın Oran, 15. Baskı, İletişim Yayınları, İstanbul, 2009, s. 777.

62 Gençalp, a.g.e., s. 65.

63 Abdi İpekçi, "Türk-Sovyet İlişkileri ve Bizim Radyo", Milliyet Gazetesi, 29 Haziran 1970, s. 11. 
durağanlığı da beraberinde getirmişti. Bu durağanlık Yüce Sovyet Presidyum Başkanı Podgorni'nin Türkiye'yi ziyareti ile biraz da olsa değişmişti. ${ }^{64}$

Sovyetler Birliği ile ilişkiler, her ne kadar Bizim Radyo meselesinin çözüme kavuşmaması, kamuoyunda tepkilere neden olmasına karşın, iyileşmeye devam etmişti. 11-17 Nisan 1972 tarihinde Yüce Sovyet Presidyum Başkanı Podgorni'nin Türkiye ziyareti, iki ülke ilişkilerine yeni bir boyut kazandırmıştı. İki ülke arasında imzalanan "İyi Komşuluk İlkeleri Bildirgesi” ilişkilerin göstergesi olmuştu. Bu havada Türk yetkililer bir kez daha Bizim Radyo konusunu gündeme getirmişlerdi. Rus heyeti diğer görüşmelerde olduğu gibi radyonun başka ülkeden yayın yaptığını belirterek, yine aynı cevabı vermişlerdi. ${ }^{65}$

Türkiye'nin dış politikada yalnızlığını sonlandırması ve üçüncü dünya ülkeleri dâhil daha kapsamlı bir dış politika benimsemesi Doğu-Batı Bloku ilişkilerini de rahatlatmıştı. 14 Ekim 1973 tarihinde yapılan Milletvekili Genel Seçimi sonucunda Bülent Ecevit yönetimindeki CHP'nin ilk sırada yer alması ve Bülent Ecevit'in başbakan olması, Sovyetler Birliği ilişkileri içinde büyük umut oluşturmuştur. Bülent Ecevit, başbakanlığ sürecinde Sovyetler Birliği ilişkilerini iyileştirmeye çalışırken diğer ülkelerle de ilişsilere büyük önem vermişti. Kıbrıs Barış Harekâtı, Türkiye'nin dış politika dengelerini sarsmıştı. Bizim Radyo, Türkiye'nin gerçekleştirdiği barış harekâtına karşı çıkmış ve harekât öncesinde duruma (Kıbrıs Devleti'ne) dönülmesi gerektiğini savunmuş, yayınlarını bu doğrultuda yapmıştı. Bizim Radyo, Sovyetler Birliği'nin görüşünü savunmaktaydı. Bu durum ilişkilere de yansımıştı. Sovyetler Birliği resmi temasların tamamında Türkiye'nin Kıbrıs'tan askerlerini çekmesini istemişti. ${ }^{66}$

\section{Bizim Radyo'nun Yayınlarma Son Vermesi}

Bizim Radyo önemli bir misyon ile kurulmuştu. TKP Dış Büro'nun yayın organı olan Bizim Radyo'nun, gerek dış politikada gerekse iç politikada temsili bir önemi vardı. Türkiye ile Sovyetler Birliği ilişkilerinin şekillenmesinde rol oynarken, ülkedeki birçok insanın hafızasında yer etmiştir. Kuruluşundan itibaren birçok değişiklik geçiren Bizim Radyo, yayınlarını Türkiye'deki ve dünyadaki gelişmelere göre şekillendirmiştir. Kimi zaman sert üslubu benimsemişti. Bizim Radyo'nun konumu aynı zamanda TKP Dış Büro'nun konumuyla paraleldi. Türkiye'de yeni siyasi hava, birçok siyasi partinin kurulmasına neden olmuştu. Bu durum TKP Dış Büro'yu harekete geçirmişti. 21-23 Mayıs 1989 tarihlerinde Türkiye Birleşik Komünist Partisi Politbüro’nun

${ }^{64}$ Kemal H. Karpat, Türk Dış Politikası, Timaş Yayınları, İstanbul, 2012, s. 287.

65 Tellal, a.g.e., 2009, s. 778.

66 Karpat, a.g.e, s. 288. 
yurtdışındaki üyeleri önemli bir toplantı gerçekleştirdiler. Toplantıya Türkiye İşçi Partisi'nden de katılım gerçekleştirilmişti. Toplantının ana konusu, TKP Dış Büro'nun lağvedilip üyelerinin Türkiye'ye dönerek resmi bir TKP kurmasıydı. Toplantı öncesinde partinin önde gelenlerine danıșılmıștı. Bu isimlerden bazıları Türkiye'ye dönmeyi desteklerken, bazıları ise karşı çıkmıştı. Sovyetler Birliği bu süreçte çekimser kalmış, tepki vermekten çekinmişti. Demokrat Almanya Cumhuriyeti ise Türkiye Birleşik Komünist Partisi'nin (TBKP) bu hamlesini desteklemişti. Toplantıda tartışmalar sonrasında yurda dönme kararı alınmıştı. Bu karar doğrultusunda temsili adımlar atılmalıydı. Bunun üzerine yıllardır varlığını gösteren, Türkiye ile Sovyetler Birliği ilişkilerinin iyileşmesinde engellerden birisi olan, içeride ve dışarıda eleştirilerin odaklarından Bizim Radyo'nun kapatılmasına karar verilmişti. Radyonun kapatılması gerekçesi olarak da Türkiye'de ve Avrupa'daki politik durumdaki değişiklikler gösterilmişti. Oysa Bizim Radyo yıllarca gerek Türkiye'de gerekse dünyada yaşanan gelişmelere ayak uydurmuştu. Türkiye'ye dönerek burada parti faaliyetlerinde bulunmak amaciyla radyo yayınlarına son verilmiști. Bizim Radyo'nun yayın hayatına son verilme kararı her ne kadar sözü geçen toplantıda alınsa da öncesinde sinyaller verilmişti. Radyo, 1987 yılında kapsamlı bir küçülmeye gitmişti. 34 olan radyo çalışan sayısı, 6'ya düşürülmüştü. Bu küçülme ile zayıflayan Bizim Radyo iki yıl sonra yayın hayatından çekilmişti. Almanya Sosyalist Birlik Partisi Genel Sekreteri Erich Honecker'e gönderilen 1 Haziran 1989 tarihli mektupta, Bizim Radyo yayınlarının sonlandırılması kararı belirtilmişti. Alınan karar doğrultusunda 11 Haziran 1989 tarihi itibariyle Bizim Radyo yayınlarına son verilmiştir. Bizim Radyo istasyonunun sökümü ise Eylül ayının sonuna kadar sürmüştür. ${ }^{67}$

\section{Sonuç}

Radyo yayıncılığı, propaganda faaliyetleri için önemli bir değişim sağlamıştır. Birinci Dünya Savaşı sonrasında askeri alandan çıkan radyo, atılan adımlar sayesinde günlük hayatın bir parçası olmuştu. Radyo yayıncılığı ülkedeki gelişmeleri aktaran, kültür sanat programlarının yanı sıra müzik programları ile eğlence aracı haline gelmişti. Her geçen gün artan radyo alıcıları sayesinde, radyo yayınları propaganda faaliyetleri için büyük kolaylık sağlamıştır. Radyo sayesinde propaganda yayınları kolayca evlere ulaşabilmekteydi. Radyo yayınlarının kontrolünün imkânsız olması, İkinci Dünya Savaşı yıllarında bir propaganda aracı olarak kullanılmasını sağlamıştı. Bu alandaki teknolojik gelişmeler sayesinde kilometrelerce

67 Anjel Açıkgöz, a.g.e., http://www.tustav.org/2018/04/01/radyo-60-yasinda/ (Erişim Tarihi: 11.12.2019); https://www.urundergisi.com/makaleler.php?ID=1615 (Erișim Tarihi: 10.12.2019); Milliyet Gazetesi, "Bizim Radyo Yayınlarına Son”, 09 Haziran 1989, s. 14. 
uzaklıktaki topraklara, bir ülkeden bir başka ülkeye yayın yapılabilmekteydi. Propaganda yayınları, devlet yayınlarının tek düze içeriklerinden farklı olarak müzik yayınları yapmakta ve çok dilli yayınları ile ilgiyle takip edilmekteydi. $\mathrm{Bu}$ durum radyo yayınlarına ilgiyi artırırken, daha çok dinlenmek için yayın içeriklerinin zenginleşmesini sağlamıştı.

Türkiye'de radyo işletmeciliği her ne kadar Cumhuriyetin ilk yıllarında başlasa da gelişimi son derece yavaş olmuştur. Radyo işletmeciliği uzun yıllar devlet tarafından sürdürülmüştür. Ülkede her ne kadar bu konuda atılan adımlar olsa da çağdaşlarına göre çok gerideydi. Bu durum İkinci Dünya Savaşı yıllarında birçok propaganda radyosunun Türkiye'de takip edilmesine neden olmuştu. Her ne kadar Nazi Almanyası ön planda olsa da Sovyetler Birliği'nin propaganda radyoları da yayın yapmaktaydı.

Soğuk Savaş yıllarında radyo yayınları yeniden düzenlenmiş, teknolojik gelişmeler sayesinde daha da güçlenmişti. Soğuk Savaş'ın güç göstergesi olan propaganda araçlarında radyo ön plandaydı. Sovyetler Birliği ve ABD'ye ait radyolar birçok ülkeye çok dilli yayınlar yapmaktaydı. Bu radyolardan birisi de TKP Dış Büro tarafından Demokratik Almanya Cumhuriyeti'nde kurulan Bizim Radyo'ydu. Demokratik Almanya Cumhuriyeti'nin Leipzig şehrinden yayın yapan ve ağırlıklı olarak Türkçe hazırlanan radyo yayınları, kısa sürede ilgiyle karşılanmıştı. Nazım Hikmet'in yanı sıra birçok önemli ismin katkı sağladığı radyo, TKP Dış Büro kontrolündeydi. Bizim Radyo her ne kadar siyasi söylevlerden ilk yıllar uzak kalmaya çalışsa da, kısa sürede Soğuk Savaş'ın gergin havasından etkilenmiş ve sert bir dil benimsemişti. Kısa sürede radyonun yayınları Türkiye'de tepkiye neden olmuştu. Türkiye'deki yöneticileri hedef alan yayınlar tepkiyle karşılaşmıştı. Bizim Radyo'nun bu tutumu, Türkiye ile Sovyetler Birliği ilişkilerinin de şekillenmesinde önemli rol oynamıştır. İki ülke görüşmelerinde Bizim Radyo yer almış, Türk yetkililer tarafından radyo yayınlarına son verilmesi, ilişkilerin iyileşmesi için ön şart olarak sunulmuştu. Sovyetler Birliği yetkilileri ise radyo yayınlarının ülke topraklarından yapılmadığını belirterek, Türkiye'nin talebine olumlu yanıt vermemişlerdi. Sovyetler Birliği'nin her defasında radyo yayınlarında Sovyetlerin etkisinin olduğu iddialarını reddetmesine karşın Türk yetkililer tüm görüşmeler de bu durumun altını çizmişlerdir. Türkiye'nin bu yönde talepleri, Bizim Radyo'nun yayınlarının sonlandırılmasına kadar devam etmiştir.

Türkiye, propaganda radyolarının dinlenmesini engellemek için ülkedeki radyo işletmeciliğini güçlendirmeye çalışıştır. Ancak bu süreç istenildiği gibi ilerleyememiştir. Türkiye, propaganda radyolarının gerisinde kalmıştır. Soğuk Savaş'ın gergin sürecinde, Bizim Radyo siyasiler tarafından 
kullanılan argümanlardan birisi olmuştur. Bunu en dikkat çeken örneği ise Demokrat Partililerin, Bizim Radyo ile Cumhuriyet Halk Partisi'nin ilişkisinin olduğunu iddia etmeleridir. Oysa Bizim Radyo, Türkiye'de TKP dışında herhangi bir yapı ile bağlantılı değildi. Bunun yanı sıra kimi zaman sol yapıyı da sert bir şekilde eleştirmekteydi.

Bizim Radyo ekonomik nedenler başta olmak üzere, kısa süre sonra çeşitli sorunlarla karşı karşıya kalmıştır. İlk yıllarda benimsediği yumuşak dilin yerine sert ve suçlayıcı bir dil kullanılması, tepkilerin artmasına neden olmuştu. $\mathrm{Bu}$ tutumun yanı sıra yayınlarının ekonomik nedenlerden ötürü kısıtlamalara gidilmesi ile radyo kapanma sürecine girmiştir. Bunun yanı sıra Türkiye'deki siyasi gelişmelerin, TKP Dış Büro üyelerinin ülkeye dönerek siyaset yapma firsatı sunduğuna inanılmaktaydı. $\mathrm{Bu}$ nedenle görevli sayısı altıya düşmüş olan ve yıllardır tartışma odaklarından birisi olan Bizim Radyo, 11 Haziran 1989 tarihinde yayınlarına son verilmiştir.

\section{KAYNAKÇA}

Arşivler

CIA, 1957-59 Propaganda Forgeries, CIA-RDP78-00915R001200080005-5.

CIA, Broadcasts to Turkey, CIA-RDP78-03061A000400070004-8.

CIA, Sino-Soviet Bloc Propaganda Forgeries 1 January 1957 to 1 July 1959, March 1960, CIA-RDP78-02646R000300130001-0.

CIA, The Soviet Foreign Propaganda Apparatus, April 1984, CIARDP87T00787R000200170003-4.

CIA, Turkey: A Regime in Trouble, 4 June 1971, CIA-RDP79R00967A0014000 30009-5.

CIA, Turkish Communist Sees Coup in Turkey as Step Forward, 8 Temmuz 1960, CIA-RDP78-03107A000600020021-1.

\section{Resmi Yayınlar}

TBMM Tutanak Dergisi

TBMM, Milletvekilleri Seçimi Kanunun Bazı Maddelerinin Değiştirilmesine ve Bazı Maddelerinin Kaldırılmasına Dair Kanun Layihası ve Dâhiliye, Teşkilatı Esasiye ve Adliye Encümenlerinin Mazbataları, Devre 10, İçtima: F, 13 Haziran 1954.

Türkiye Cumhuriyeti Dışişleri Bakanlığı Belleteni. 


\section{Kitaplar}

Açıkgöz, Anjel, Bizim Radyoda Nazım Hikmet, Tüstav Yayınları, İstanbul, 2004.

Açıkgöz, Hayk, Anadolulu Bir Ermeni Komünistin Anıları, Belge Yayınları, İstanbul, 2006.

Akbulut, Erden, Anılar Bilal Şen, Tüstav Yayınları, İstanbul, 2008.

Akbulut, Erden, TKP 1965 Tartışmaları Muhalefet Mektupları, Sosyal Tarih Yayınları, İstanbul 2011.

Akbulut, Erden, TKP MK Dış Bürosu 1965 Tartışmaları, Tüstav Yayınları, İstanbul, 2004.

Aziz, Aysel, Radyo ve Televizyona Giriş, Ankara Üniversitesi Siyasal Bilgileri Fakültesi Yayınları, Ankara,1981.

Bilen, Mara Kolarova, Kanatlı Gençlik, Çev. Cemal Kıral, Türkiye Sosyal Tarih Araştırma Vakfi Yayınları, İstanbul, 2003.

Çankaya, Özden, Bir Kitle İletişim Kurumu Tarihi TRT 1927-2000, Yapı Kredi Yayınları, İstanbul, 2003.

Devran, Yusuf, Siyasal İktidar-TRT İlişkisinin Dünü, Başlık Yayın Grubu Yayınları, İstanbul, 2011.

Erer, Tekin, Yassıada ve Sonrası, Rek-Tur Kitap Servisi, İstanbul, 1965.

Ersan, Cavit, Zindanlar, Sinan Yayınevi, İstanbul, 1975.

Ersan, Vehbi, 1970'lerde Türkiye Solu, İletişim Yayınları, İstanbul, 2014.

Gökay, Bülent, Soviet Eastern Policy and Turkey, 1920-1991: Soviet Foreign Policy, Turkey and Communism, Routledge Taylor and Francis Group, New York, 2006.

Henze, Paul B., Turkey and Atatürk's Legacy: Turkey's Political Evolution, Turkish-US Relations and Prospects fort he 21st Century, Research Centre for Turkestan and Azerbaijan Publishing, 1998.

İhmalyan, Vartan, Bir Yaşam Öyküsü, Cem Yayınevi, İstanbul, 1989.

Karpat, Kemal H., Türk Dış Politikası, Timaş Yayınları, İstanbul, 2012.

Kıyanç, Sinan, CIA ve Türkiye'de Darbeler, 27 Mayıs 1960 Darbesi, 12 Mart 1971 Muhtırasi, 12 Eylül 1980 Darbesi, Talat Aydemir ve Eminsu Darbe Girişimleri, Duvar Yayınları, İzmir, 2020.

Kirişçioğlu, Nusret, 12 Mart (İnönü-Ecevit) ve 1960 Tahkikat Encümeni Raporum, Baha Matbaasi, Ankara,1973.

Qasımlı, Musa, Türkiye-Sovyet Sosyalist Cumhuriyetleri Birliği İlişkileri 19601980, Atam Yay., Ankara 2013. 
Sayılgan, Aclan, Bizim Radyo ve Hoparlörleri, Kardeş Matbaası, Ankara, 1969.

Seydi, Süleyman, Zor Yıllar 2. Dünya Savaşı'nda Türkiye'de İngiliz-Alman Propaganda ve İstihbarat Savaşı 1939-1945, Asil Yayın, Ankara 2006.

Tellal, Eren, "SSCB’le İlişkiler”, Türk Dış Politikası Kurtuluş Savaşından Bugüne Olgular, Belgeler, Yorumlar, Cilt 1: 1919-1980, ed. Baskın Oran, 15. Baskı, İletişim Yayınları, İstanbul, 2009.

Tellal, Eren, Uluslararası ve Bölgesel Gelişmeler Çerçevesinde SSCB-Türkiye İlişkileri 1953-1964, Mülkiyeliler Birliği Vakfı Yayınları, Ankara, 2000.

TÜSTAV, TKP Gölcük Davası, TKP'nin Sesi Radyosu “Nerde Bir Komünist Varsa Parti Ordadır", Tüstav Yayınları, İstanbul, 2004.

Ünlü, Barış, Bir Siyasal Düşünür Olarak Mehmet Ali Aybar, İletişim Yayınları, İstanbul 2002.

Wasburn, Philo C., Broadcasting Propaganda: International Radio Broadcasting and the Construction of Political Reality, Praeger Pub., 1992.

Makaleler

Akça, Bayram ve Sinan Kıyanç, "CIA ve 27 Mayıs 1960 Darbesi”, Tarih Okulu Dergisi, Say1: 36, (2018), s. 528-564.

Arvas, İbrahim Sen, “Türkiye'nin Radyo ile Tanışması ve Türk Telsiz Telefon Anonim Şirketi”, International Journal of Cultural and Social Studies (IntJCSS), C. 4, Say1: 2, (2018), s. 406-428.

Ecevit, Bülent, “’Bizim Radyo ve Bizim Radyo” Ulus, 14 Şubat 1961, s. 1-2.

Gençalp, Ebru, “Sovyet Başbakanı Kosıgin’in Türkiye’yi Ziyaretinin Basında Değerlendirilmesi”, Hacettepe Üniversitesi Türkiyat Araştırmaları Dergisi, Sayı: 30, Ankara, (Bahar 2019), s. 55-77.

Henze, Paul B., "Out of Kilter-Greeks, Turks \& U.S. Policy", The National Interest, Sayı: 8, (Summer 1987), s. 71-82.

İlaslan, Süleyman, "Ulusal Bütünlükten Kültürel Yozlaşmaya: Türkiye’de Yabancı Radyoların Dinlenmesinden Duyulan Kaygılar", İlef Dergisi, C. 3, Sayı: 2, (2016), s. 23-51.

Juniper, Dean, "The First World War and Radio Development", The RUSI Journal, C. 148 , Say1:1, (2003), s. 84-89.

Karpat, Kemal, "Socialism and The Labor Party of Turkey", Middle East Journal, C. 21, Sayı: 2, (Spring 1967), s. 157-172.

Kıyanç, Sinan, Soğuk Savaş Yıllarında Türkiye'deki ABD Üs ve Tesisleri, Atatürk Araştırma Merkezi Dergisi, Sayı: 101, (2020), s. 203-251. 
Kurban, Vefa, "1950-1960 Yillarında Türkiye ile Sovyetler Birliği Arasındaki İlişkiler”, Çağdaş Türkiye Tarihi Araştırmaları Dergisi, C. 14, Sayı: 28, (2014), s. 253-282.

Kuyucu, Mihail, "Radyonun Müzik Kutusuna Dönüşümü: Radyo Program Türleri ve Tercih Edilirken Oranları", E-Journal New World Science Academy, C. 8, Say1: 4, (Mayıs 2013), s. 372-400.

Mark D. Winek, "Radio as a Tool of the State: Radio Moscow and the Eartly Cold War", Comparative Humanities Review, Say1: 3, (2009), s. 99-113.

Polat, Necla, “1946 Çok Partili Dönemin Başlangıcından 1964 TRT’nin Kurulmasına Kadar Türkiye'de Radyo Yayıncılığı”, İstanbul Aydın Üniversitesi Dergisi, C.10, Sayı: 1, (2018), s. 125-137.

Risso, Linda, "Radio Wars: Broadcasting in the Cold War", Cold War History, C. 13, Say1: 2, (2013), s. 145-152.

Tamer, Aytül, "Muhayyel Komünizm: Türk Sağının Anti-Komünizm Propagandası", Doğu Batı Dergisi, S. 58, 2011, s. 91-112.

\section{Süreli Yayınlar (Gazete ve Dergiler)}

Hürriyet

Milliyet

Resmî Gazete

The New York Times

Yön (Dergi)

\section{İnternet Kaynakları}

http://www.tustav.org/2018/04/01/radyo-60-yasinda/ (Erişim Tarihi: 11.12.2019); https://www.urundergisi.com/makaleler.php?ID=1615 (Erişim Tarihi: 10.12.2019).

https://www.milliyet.com.tr/pazar/hicbir-zaman-bagnaz-stalinci-olmadim149365/(Erişim Tarihi: 11.06.2020).

https://www.urundergisi.com/makaleler.php?ID=1615 (Erişim Tarihi: 10.12.2019). 
EKLER

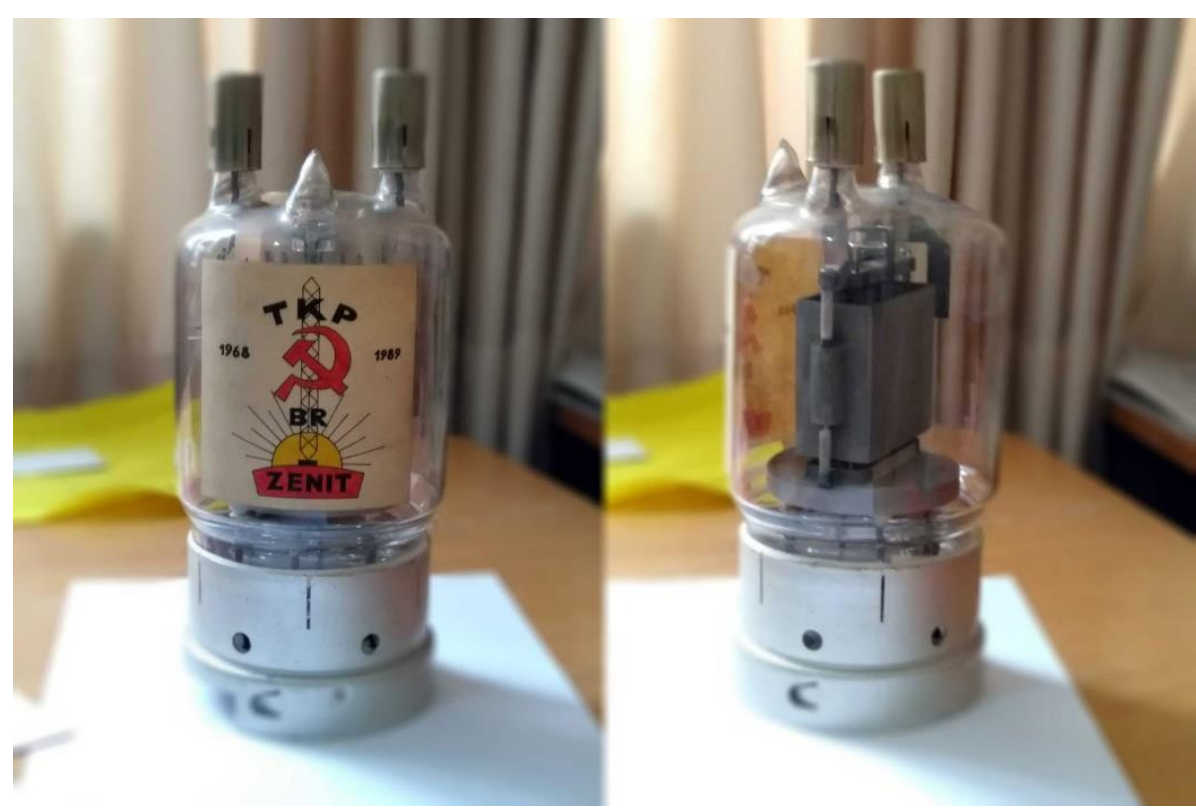

Ek 1: Bizim Radyo Vericisi (Tüstav Arşivi) 


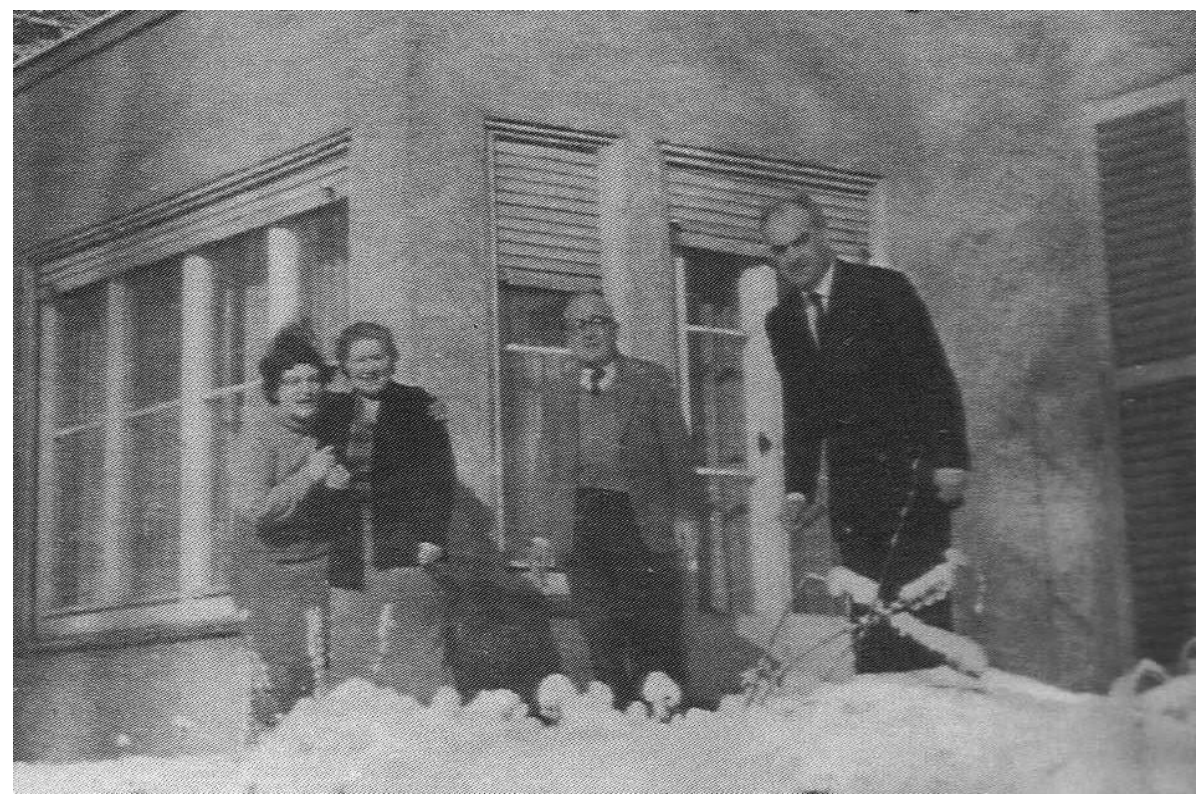

Ek 2: Bizim Radyo binası Anjel Açıkgöz, Sabiha Sertel, Zekeriya Sertel, Aram Pehlivanyan (TÜSTAV arşivi)

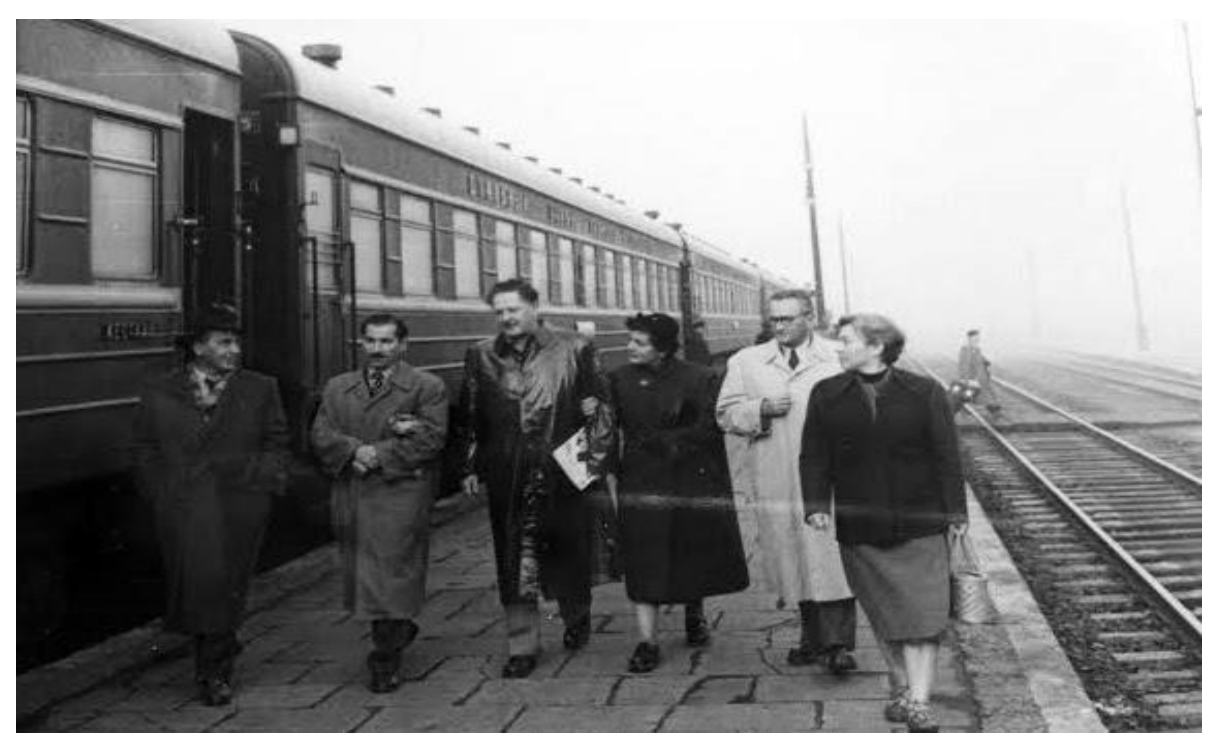

Ek 3: Nazım Hikmet Bizim Radyo Faaliyetleri için Leipzig’te 